\title{
Influence of Heating Rate and Soaking Temperature during Case-Hardening on the Hardness and Grain Size of Ultra-Clean Gear Steels
}

\author{
Einfluss der Aufheizrate und der Haltetemperatur \\ während des Einsatzhärtens auf die Härte und die \\ Korngröße von hochreinen Zahnradstählen
}

In the framework of a research project, the tooth root bending strength of high-strength gears is investigated. The most common type of failure encountered with these shot-peened, case-hardened gears is tooth root breakage caused by a crack initiation below the surface at a non-metallic inclusion (fisheye failure). However, it is well known that case-hardening depth and quenching grain size can have a great influence on a gear's load carrying capacity. To ensure that this research project solely investigates the influence of non-metallic inclusions, any cross-influences must be excluded or minimized, or at least known. However, in the case of such ultra-clean gear steels, no recommendations or investigations of the influence of case-hardening on material properties are currently available. Therefore, in the framework of this paper, extended investigations are conducted into the effects of different process steps during case-hardening on the resulting material properties of ultra-clean gear steels.

Keywords: Heat treatment, heating rate, soaking temperature, furnace duration time, case-hardening, case-hardening depth, surface hardness, core hardness, grain size, gear steel, ultra-clean steel, gear
Im Rahmen eines Forschungsprojektes wird die Zahnfußtragfähigkeit von hochtragfähigen Zahnrädern untersucht. Die häufigste Versagensart bei diesen kugelgestrahlten, einsatzgehärteten Zahnrädern ist der Zahnfußbruch, der durch eine Rissbildung unterhalb der Oberfläche an einem nichtmetallischen Einschluss verursacht wird (fisheye failure oder Bruchlinsenversagen). Es ist jedoch bekannt, dass Einsatzhärtetiefe und Abschreckkorngröße einen großen Einfluss auf die Tragfähigkeit eines Zahnrades haben können. Um sicherzustellen, dass in diesem Forschungsprojekt ausschließlich der Einfluss von nichtmetallischen Einschlüssen untersucht wird, müssen eventuelle Quereinflüsse ausgeschlossen oder minimiert werden, zumindest aber bekannt sein. Für solche hochreine Zahnradstähle liegen jedoch derzeit keine Empfehlungen oder Untersuchungen über den Einfluss des Einsatzhärtens auf die Werkstoffeigenschaften vor. Daher werden im Rahmen dieser Veröffentlichung erweiterte Untersuchungen zu den Auswirkungen verschiedener Prozessschritte beim Einsatzhärten auf die resultierenden Werkstoffeigenschaften von hochreinen Zahnradstählen durchgeführt.

Schlïsselwörter: Wärmebehandlung, Aufheizrate, Haltetemperatur, Ofenverweildauer, Einsatzhärtung, Einsatzhärtungstiefe, Oberflächenhärte, Kernhärte, Korngröße, Zahnradstahl, hochreine Stähle, Zahnrad

Authors/Autoren: M.Sc. Daniel Fuchs, B.Sc. Sascha Rommel, Dr.-Ing. Thomas Tobie, Prof. Dr.-Ing. Karsten Stahl, Forschungsstelle für Zahnräder und Getriebebau (FZG), Technische Universität München, Boltzmannstraße 15, 85748 Garching bei München, fuchs@fzg.mw.tum.de (Corresponding author/Kontakt) Thomas Blum, ZF Friedrichshafen AG, Graf-von-Soden-Platz 1, Zentrale Forschung und Entwicklung, 88046 Friedrichshafen 


\section{Introduction}

The tooth root bending strength of case-hardened gears can be increased, for example to meet higher torque demands, by applying shot-peening. Current trends towards green energy and electrification of the powertrain in particular are resulting in more stringent or even completely new requirements for gear transmissions. However, these high-strength gears are susceptible to fisheye failure, even in the very high cycle fatigue range. Fisheye failure usually begins below the surface at a non-metallic inclusion. Much effort has been invested in reducing the incidence of non-metallic inclusions in gear steels. However, no proper correlation has as yet been determined between the degree of cleanliness or amount of non-metallic inclusions and the tooth root bending strength. This research project therefore investigates the influence of the degree of cleanliness and the incidence of non-metallic inclusions on tooth root bending strength.

Similarly, it is well known that case-hardening depth and quenching grain size can also have a considerable influence on a gear's load carrying capacity. To ensure that this research project solely investigates the influence of non-metallic inclusions, any cross-influences must be excluded or minimized, or at least known. However, to date, no recommendations or investigations regarding the influence of different process steps during the case-hardening process on the resulting material properties have been conducted for ultra-clean gear steels. Even gear steels with high fine-grain stability can contain quantities of coarser grains following unsuitable heat treatment. This paper therefore presents extended investigations into the influence of various process steps conducted during case-hardening on the resulting material properties of two distinct batches of ultra-clean gear steels. These heat treatments were performed at ZF Friedrichshafen AG, Materials Technology.

\section{State of scientific knowledge}

Case-hardening influences important gear properties. This section outlines a number of influencing factors of the case-hardening process on the tooth root load carrying capacity of gears.

\subsection{Core hardness}

According to Niemann and Winter [1], core strength mainly influences a gear's tooth root load carrying capacity in terms of its static and finite life fatigue strength. Higher strength numbers can generally be achieved with increasing core hardness values up to

\section{Einleitung}

Die Zahnfußtragfähigkeit von einsatzgehärteten Zahnrädern kann durch Kugelstrahlen erhöht werden, um beispielsweise höhere Drehmomentanforderungen zu erfüllen. Insbesondere die aktuellen Trends zu grüner Energie und zur Elektrifizierung des Antriebsstrangs führen zu verschärften oder sogar völlig neuen Anforderungen an Zahnradgetriebe. Diese hochtragfähigen Zahnräder sind jedoch anfällig für Bruchlinsenversagen (fisheye failure), auch im Bereich sehr hoher Lastwechsel. Fisheye failure oder Bruchlinsenversagen beginnt in der Regel unterhalb der Oberfläche an einem nichtmetallischen Einschluss. Es wurden unlängst große Anstrengungen unternommen, um die Häufigkeit von nichtmetallischen Einschlüssen in Zahnradstählen zu verringern. Es wurde jedoch noch kein geeigneter Zusammenhang zwischen dem Reinheitsgrad oder der Menge der nichtmetallischen Einschlüsse und der Zahnfußtragfähigkeit festgestellt. In diesem Forschungsprojekt wird daher der Einfluss des Reinheitsgrades und des Auftretens von nichtmetallischen Einschlüssen auf die Zahnfußtragfähigkeit untersucht.

Ebenso ist bekannt, dass auch die Einsatzhärtungstiefe und die Abschreckkorngröße einen erheblichen Einfluss auf die Tragfähigkeit eines Zahnrades haben können. Um sicherzustellen, dass in diesem Forschungsprojekt ausschließlich der Einfluss von nichtmetallischen Einschlüssen untersucht wird, müssen eventuelle Quereinflüsse ausgeschlossen oder minimiert werden oder zumindest bekannt sein. Für hochreine Zahnradstähle liegen jedoch bisher keine Empfehlungen oder Untersuchungen zum Einfluss verschiedener Prozessschritte während des Einsatzhärteprozesses auf die resultierenden Werkstoffeigenschaften vor. Auch Zahnradstähle mit hoher Feinkornstabilität können nach einer ungeeigneten Wärmebehandlung Anteile an gröberen Körnern enthalten. In dieser Arbeit werden daher erweiterte Untersuchungen zum Einfluss verschiedener Prozessschritte beim Einsatzhärten auf die resultierenden Werkstoffeigenschaften von zwei unterschiedlichen Chargen hochreiner Zahnradstähle vorgestellt. Diese Wärmebehandlungen wurden bei der zentralen Werkstofftechnik der ZF Friedrichshafen AG durchgeführt.

\section{Stand der wissenschaftlichen Erkenntnisse}

Die Einsatzhärtung beeinflusst wichtige Eigenschaften von Zahnrädern. In diesem Abschnitt wird eine Reihe von Einflussfaktoren des Einsatzhärteverfahrens auf die Zahnfußtragfähigkeit von Zahnrädern dargestellt.

\subsection{Kernhärte}

Nach Niemann und Winter [1] beeinflusst die Kernhärte vor allem die Zahnfußtragfähigkeit eines Zahnrades in Bezug auf die statische Festigkeit und Zeitfestigkeit. Höhere Festigkeitswerte können im Allgemeinen mit steigenden Kernhärtewerten bis etwa 
about $420 \mathrm{HV}$. However, according to [1], the effect on endurance fatigue strength is less pronounced. Above a core hardness value of about $450 \mathrm{HV}$, the positive effect of higher core hardness appears to decline again [2]. Funatani [3] also investigated the effect of core hardness on tooth root load carrying capacity. However, due to the small data basis, the findings only reflect tendencies. They show that the highest load carrying capacity for chromium-molybdenum case-hardened steels (JIS SCM 21 and 22) occurs in the core hardness range of 300 to $440 \mathrm{HV}$. Moreover, a reduction was observed for core hardnesses above $450 \mathrm{HV}$. In FVA (FVA: Forschungsvereinigung Antriebstechnik e.V. (German Drive Technology Research Association)) research project 8 [4], investigations of gears made of $16 \mathrm{MnCr} 5$ gear steel also found that the tooth root load carrying capacity depends on the core hardness. The highest load carrying capacity values were obtained in the core hardness range between about 440 and 470 HV0.3. It was stated that a decline in load carrying capacity is to be expected at a lower and higher core hardness. Recent investigations in FVA research project 740 I [5] also confirmed that there is no influence on the endurance fatigue strength for gear steels with higher hardenability.

\subsection{Case-hardening depth}

With regard to the tooth root load carrying capacity, Niemann and Winter [1] specify a range of $0.1 \ldots 0.2 \times \mathrm{m}_{\mathrm{n}}\left(\mathrm{m}_{\mathrm{n}}\right.$ : normal module) as the optimum case-hardening depth $\left(\mathrm{CHD}_{550 \mathrm{HV} 1}\right)$. For case-hardening depths exceeding $0.3 \times \mathrm{m}_{\mathrm{n}}$, a strong decrease in tooth root load carrying capacity is to be expected. In FVA research projects 8 [4] and 271 [6], investigations on gears made of $16 \mathrm{MnCr} 5$ and $20 \mathrm{MnCr} 5$ gear steels also reveal that the highest tooth root load carrying capacity is achieved at a case-hardening depth of $0.1 \ldots 0.2 \times \mathrm{m}_{\mathrm{n}}$. This range thus represents the optimum case-hardening depth in the tooth root in terms of fatigue strength. If this range is not achieved, the tooth root load carrying capacity decreases. If the values fall below this range, a stronger reduction is to be expected than with higher values in the tooth root. If the $\mathrm{CHD}$ is too low, it is due to the steep hardness or strength gradient and the associated low support of the surface layer. At higher CHD values, the intergranular oxidation depth increases and grain coarsening may occur; also lower compressive residual stresses have been determined. These influencing variables are known to have a negative effect on tooth root load carrying capacity. This is also confirmed by industrial applications. According to [7], a case-hardening depth in the range of $0.1 \ldots 0.25 \times \mathrm{m}_{\mathrm{n}}$ represents the optimum in terms of tooth root load carrying capacity. However, the materials investigated were not recorded. In [3], the highest tooth root load carrying capacity is achieved at a case-hardening depth of $0.1 \times m_{n}$.

\subsection{Grain size}

The term "grain size" is used in this paper to refer to prior austenite grain size. According to [8], coarse grain has a negative effect on the tooth root bending strength, particularly in the case-hardened surface layer. Given that carburizing temperatures of up to
420 HV erreicht werden. Nach [1] ist die Auswirkung auf die Dauerfestigkeit jedoch weniger ausgeprägt. Oberhalb einer Kernhärte von etwa $450 \mathrm{HV}$ scheint die positive Wirkung höherer Kernhärten wieder abzunehmen [2]. Funatani [3] untersuchte ebenfalls den Einfluss der Kernhärte auf die Zahnfußtragfähigkeit. Aufgrund der geringen Datenbasis geben die Ergebnisse jedoch nur Tendenzen wieder. Sie zeigen, dass die höchste Tragfähigkeit für Chrom-Molybdän-Einsatzstähle (JIS SCM 21 und 22) im Kernhärtebereich von 300 bis $440 \mathrm{HV}$ auftritt. Darüber hinaus wurde eine Verringerung bei Kernhärten über 450 HV beobachtet. Im FVA-Forschungsprojekt 8 [4] wurde bei Untersuchungen von Zahnrädern aus dem Zahnradstahl 16MnCr5 ebenfalls eine Abhängigkeit der Zahnfußtragfähigkeit von der Kernhärte festgestellt. Die höchsten Tragfähigkeitswerte wurden im Kernhärtebereich zwischen etwa 440 und 470 HV0,3 erreicht. Es wurde festgestellt, dass sowohl bei geringerer als auch bei höherer Kernhärte eine Abnahme der Tragfähigkeit zu erwarten ist. Auch neuere Untersuchungen im FVA-Forschungsvorhaben 740 I [5] bestätigten, dass bei Zahnradstählen mit höherer Härtbarkeit kein Einfluss auf die Dauerfestigkeit besteht.

\subsection{Einsatzhärtungstiefe}

Im Hinblick auf die Zahnfußtragfähigkeit geben Niemann und Winter [1] einen Bereich von $0,1 \ldots 0,2 \times \mathrm{m}_{\mathrm{n}}\left(\mathrm{m}_{\mathrm{n}}\right.$ : Normalmodul $)$ als optimale Einsatzhärtetiefe an $\left(\mathrm{CHD}_{550 \mathrm{HV} 1}\right)$. Bei Einsatzhärtungstiefen von mehr als $0,3 \times \mathrm{m}_{\mathrm{n}}$ ist eine starke Abnahme der Zahnfußtragfähigkeit zu erwarten. In den FVA-Forschungsprojekten 8 [4] und 271 [6] zeigen Untersuchungen an Zahnrädern aus $16 \mathrm{MnCr} 5-$ und 20MnCr5-Zahnradstählen ebenfalls, dass die höchste Zahnfußtragfähigkeit bei einer Einsatzhärtetiefe von $0,1 \ldots 0,2 \times \mathrm{m}_{\mathrm{n}}$ erreicht wird. Dieser Bereich stellt somit die optimale Einsatzhärtungstiefe im Zahnfuß im Hinblick auf die Dauerfestigkeit dar. Wird dieser Bereich nicht erreicht, sinkt die Zahnfußtragfähigkeit. Wird dieser Bereich unterschritten, ist eine stärkere Abnahme zu erwarten als bei höheren Werten im Zahnfuß. Ist die CHD zu niedrig, liegt es am steilen Härte- bzw. Festigkeitsgradienten und der damit verbundenen geringen Stützwirkung der Randschicht. Bei höheren CHD-Werten nimmt die intergranulare Oxidationstiefe zu und es kann zu einer Kornvergröberung kommen. Außerdem wurden geringere Druckeigenspannungen festgestellt. Es ist bekannt, dass sich diese Einflussgrößen negativ auf die Zahnfußtragfähigkeit auswirken. Dies wird auch durch industrielle Anwendungen bestätigt. Nach [7] stellt eine Einsatzhärtungstiefe im Bereich von $0,1 \ldots 0,25 \times \mathrm{m}_{\mathrm{n}}$ das Optimum in Bezug auf die Zahnfußtragfähigkeit dar. Die untersuchten Werkstoffe wurden jedoch nicht erfasst. In [3] wird die höchste Zahnfußtragfähigkeit bei einer Einsatzhärtungstiefe von $0,1 \times \mathrm{m}_{\mathrm{n}}$ erreicht.

\subsection{Korngröße}

Der Begriff „Korngröße“ wird in dieser Arbeit verwendet, um sich auf die ehemalige Austenitkorngröße zu beziehen. Nach [8] wirkt sich Grobkorn negativ auf die Zahnfußtragfähigkeit aus, insbesondere in der einsatzgehärteten Randschicht. Da heutzutage Aufkoh- 
$950{ }^{\circ} \mathrm{C}$ are common nowadays, [9] states that compliance with fine grain should not be a challenging matter. The tendency towards coarse grain formation has been countered by developing special fine-grain grades of case-hardening steels by alloying small portions of aluminum, niobium, vanadium, and titanium. The quantity of nitrogen also plays an important role. Micro-alloyed case-hardening steels have the potential to withstand carburizing temperatures of up to $1050^{\circ} \mathrm{C}$ without any significant grain coarsening $[10,11]$. However, despite these alloying measures, it is sometimes unavoidable that a certain proportion of coarse grain may occur at the surface layer and, above all, in the core. A small grain size can then only be achieved by adjusting the material in conjunction with the heat treatment.

\subsection{Specifications pursuant to ISO 6336, Part 5}

The gear standard ISO 6336, Part 5 [12] states the requirements for different material grades (ML, MQ and ME) of case-hardened wrought steels, see Table 1 . The material quality ME has the most stringent requirements, denoted by the maximum permitted stress numbers. The information in Table 1 is presented in abbreviated form.

\section{Background for the investigations in the framework of this publication}

FVA research project 293 IV [15], which builds on the results and conclusions of [16-23], comprises extensive experimental investigation of the tooth root bending strength of shot-peened, case-hardened gears made from ultra-clean gear steels. The focus is on the very high cycle fatigue range. The aim is to determine whether using such ultra-clean gear steel can prevent crack initiation below the surface at non-metallic inclusions (fisheye failure), whereby higher load carrying capacities are expected. One of the main goals is to correlate the load carrying capacity of shotpeened, case-hardened gears with the microscopic degree of cleanliness. The experiments are conducted on the FZG back-toback test rig and Pulsator test rig using gear sizes with a normal module of $\mathrm{m}_{\mathrm{n}}=1.5$ and $5 \mathrm{~mm}$. lungstemperaturen von bis zu $950{ }^{\circ} \mathrm{C}$ üblich sind, stellt [9] fest, dass die Einhaltung von Feinkorn keine Herausforderung darstellen sollte. Der Tendenz zur Grobkornbildung wurde durch die Entwicklung spezieller Feinkornsorten von Einsatzstählen entgegengewirkt, indem geringe Mengen von Aluminium, Niob, Vanadium und Titan zulegiert wurden. Auch die Stickstoffmenge spielt eine wichtige Rolle. Mikrolegierte Einsatzstähle haben das Potenzial, Aufkohlungstemperaturen von bis zu $1050^{\circ} \mathrm{C}$ ohne nennenswerte Kornvergröberung zu widerstehen [10, 11]. Trotz dieser Legierungsmaßnahmen ist es manchmal unvermeidbar, dass ein gewisser Anteil an Grobkorn in der Randschicht und vor allem im Kern auftritt. Eine geringe Korngröße kann dann nur durch eine Anpassung des Werkstoffs in Verbindung mit der Wärmebehandlung erreicht werden.

\subsection{Festlegungen nach ISO 6336, Teil 5}

In der Zahnradnorm ISO 6336, Teil 5 [12] sind die Anforderungen an verschiedene Werkstoffgüten (ML, MQ und ME) von einsatzgehärteten Einsatzstählen festgelegt, siehe Tabelle 1. Die Werkstoffgüte $\mathrm{ME}$ hat die höchsten Anforderungen, die durch die maximal zulässigen Spannungszahlen gekennzeichnet sind. Die Angaben in Tabelle 1 sind in verkürzter Form dargestellt.

\section{Hintergrund für die Untersuchungen im Rahmen dieser Veröffentlichung}

Das FVA-Forschungsvorhaben 293 IV [15], das auf den Ergebnissen und Schlussfolgerungen von [16-23] aufbaut, umfasst umfangreiche experimentelle Untersuchungen zur Zahnfußtragfähigkeit von kugelgestrahlten, einsatzgehärteten Zahnrädern aus hochreinen Zahnradstählen. Der Schwerpunkt liegt dabei auf dem Bereich sehr hoher Lastwechselzahlen. Es soll festgestellt werden, ob durch den Einsatz solcher hochreiner Zahnradstähle eine Rissbildung unter der Oberfläche an nichtmetallischen Einschlüssen (Bruchlinsenversagen) verhindert werden kann, wodurch höhere Tragfähigkeiten zu erwarten sind. Eines der Hauptziele ist es, die Tragfähigkeit von kugelgestrahlten, einsatzgehärteten Zahnrädern mit dem mikroskopischen Reinheitsgrad zu korrelieren. Die Versuche werden auf dem FZG-Stirnradverspannungsprüfstand und dem Pulsator-Prüfstand an Zahnrädern mit einem Normalmodul von $\mathrm{m}_{\mathrm{n}}=1,5$ und $5 \mathrm{~mm}$ durchgeführt.
Table 1. Requirements for case-hardened wrought steels (forged or rolled) for gears pursuant to ISO 6336, Part 5 [12]

(in highly condensed form)

Tabelle 1. Anforderungen an einsatzgehärtete Einsatzstähle (geschmiedet oder gewalzt) für Zahnräder nach ISO 6336, Teil 5 [12] (in stark verkürzter Form)

\begin{tabular}{|c|c|c|c|}
\hline Requirement & ML & MQ & ME \\
\hline $\begin{array}{c}\text { Grain size pursuant to } \\
\text { ISO 643 [13] }\end{array}$ & $\begin{array}{c}\text { Fine grain, with 90 \% of the area having grain size 5 and finer, and no grain } \\
\text { coarser than size 3. Test report in accordance with ISO 10474 [14] }\end{array}$ \\
\hline Surface hardness & $>600 \mathrm{HV}$ or $>55 \mathrm{HRC}$ & 660 HV to $800 \mathrm{HV}$ or 58 HRC to 64 HRC \\
\hline Core hardness & $>21 \mathrm{HRC}$ & $>25 \mathrm{HRC}$ & $>30 \mathrm{HRC}$ \\
\hline Case-hardening depth & $\begin{array}{c}\text { Case-hardening depth is defined as the distance from the surface to a point at } \\
\text { which the hardness number is 550 HV or 52 HRC respectively. } \\
\text { Recommended values for case-hardening depth are also shown in the standard }\end{array}$ \\
\hline
\end{tabular}


Current scientific knowledge shows that case-hardening depth and grain size can have a strong influence on a gear's load carrying capacity. For this reason, any cross-influences should be excluded or minimized, or at least known, to ensure that the investigation focuses solely on the influence of any non-metallic inclusions. As a result and as a first step, only gear steels that comply with the specifications of material quality ME pursuant to ISO 6336, Part 5 [12] are investigated. Furthermore, all of the gear steels should have high fine-grain stability and hardenability within narrow limits (hardenability scatter band $+\mathrm{HH}$ pursuant to DIN EN ISO 683, Part 3 [24]). However, the gear properties are susceptible to massive influencing during a heat treatment such as case-hardening. For example, even gear steels with high fine-grain stability can still contain coarse grains if subjected to inappropriate heat treatment. However, no recommendations or investigations regarding the influence of the case-hardening process on material properties are currently available for ultra-clean gear steels pursuant to the specifications in ISO 6336, Part 5 [12].

\section{Aim of the investigations}

Against this background, extended investigations into the influence of various steps in the case-hardening process on the material properties of two batches of ultra-clean gear steels are carried out in this study. In this context, the case carburizing process parameters are varied, beginning with the heating rate and followed by the carburizing time, which is adjusted until an equal furnace duration time is found for all variants. Additionally, a soaking lev$\mathrm{el}$ is inserted into the transformation zone when heating to the carburizing temperature. The aim of these investigations is to determine the influence of the variations on core hardness, surface hardness, case-hardening depth, and grain size. The fine-grain stability of these gear steels is also investigated. Some of the selected heat-treatment parameters are already known to lead to coarse grain and a lower case-hardening depth. However, the extent of the effects is not yet known for these ultra-clean gear steels.

\section{Steel batches, basic material documentation and procedure}

Table 2 contains an overview of the steel batches, alloy systems, bar diameters and reduction ratios, as well as other specific features. Both reduction ratios are above the specification value of
Aktuelle wissenschaftliche Erkenntnisse zeigen, dass Einsatzhärtungstiefe und Korngröße einen starken Einfluss auf die Tragfähigkeit eines Zahnrades haben können. Aus diesem Grund sollten Quereinflüsse ausgeschlossen oder minimiert werden oder zumindest bekannt sein, um sicherzustellen, dass sich die Untersuchung ausschließlich auf den Einfluss der nichtmetallischen Einschlüsse konzentriert. Aus diesem Grund werden in einem ersten Schritt nur Zahnradstähle untersucht, die den Vorgaben der Werkstoffqualität ME nach ISO 6336, Teil 5 [12] entsprechen. Weiterhin sollen alle Zahnradstähle eine hohe Feinkornstabilität und eine Härtbarkeit in engen Grenzen (Härtbarkeitsstreuband $+\mathrm{HH}$ nach DIN EN ISO 683, Teil 3 [24]) aufweisen. Die Verzahnungseigenschaften sind jedoch durch eine Wärmebehandlung, wie das Einsatzhärten, massiv beeinflussbar. So können z. B. auch Zahnradstähle mit hoher Feinkornstabilität bei ungeeigneter Wärmebehandlung noch grobe Körner enthalten. Für hochreine Zahnradstähle gemäß den Vorgaben der ISO 6336, Teil 5 [12] liegen jedoch derzeit keine Empfehlungen oder Untersuchungen zum Einfluss des Einsatzhärteverfahrens auf die Werkstoffeigenschaften vor.

\section{Ziel der Untersuchungen}

Vor diesem Hintergrund werden in der vorliegenden Veröffentlichung erweiterte Untersuchungen zum Einfluss verschiedener Stufen des Einsatzhärtungsprozesses auf die Werkstoffeigenschaften von zwei Chargen hochreiner Zahnradstähle durchgeführt. Dabei werden die Prozessparameter der Einsatzhärtung variiert, beginnend mit der Aufheizrate, gefolgt von der Aufkohlungszeit, die so lange angepasst wird, bis sich für alle Varianten eine gleiche Ofenverweildauer ergibt. Zusätzlich wird beim Aufheizen auf die Aufkohlungstemperatur eine Haltestufe in die Umwandlungszone eingebracht. Ziel dieser Untersuchungen ist es, den Einfluss der Variationen auf Kernhärte, Oberflächenhärte, Einsatzhärtetiefe und Korngröße zu ermitteln. Auch die Feinkornstabilität dieser Zahnradstähle wird untersucht. Von einigen der gewählten Wärmebehandlungsparameter ist bereits bekannt, dass sie zu grobem Korn und einer geringeren Einsatzhärtungstiefe führen. Das Ausmaß der Auswirkungen ist jedoch für diese hochreinen Zahnradstähle noch nicht bekannt.

\section{Stahlchargen, grundlegende Werkstoff- dokumentation und Vorgehensweise}

Tabelle 2 enthält eine Übersicht über die Stahlchargen, Legierungssysteme, Stabdurchmesser und Verformungsgrade sowie weitere spezifische Merkmale. Beide Verformungsgrade liegen

\begin{tabular}{|c|c|c|c|c|c|}
\hline $\begin{array}{l}\text { Steel } \\
\text { batch }\end{array}$ & Alloy system & $\begin{array}{l}\text { Casting } \\
\text { method }\end{array}$ & $\begin{array}{c}\text { Diameter of } \\
\text { steel bar in mm }\end{array}$ & $\begin{array}{c}\text { Reduction } \\
\text { ratio }\end{array}$ & Features \\
\hline OW4 & $20 \mathrm{MnCr} 5$ & \multirow{2}{*}{$\begin{array}{l}\text { Continuous } \\
\text { casting }\end{array}$} & 100 & \multirow{2}{*}{$8: 1$} & Low sulfur content \\
\hline OW3 & 18CrNiMo7-6 & & 140 & & Modified rolling/forging process \\
\hline
\end{tabular}

Table 2. Overview of the investigated test steel batches and their characteristics

Tabelle 2. Übersicht über die untersuchten Stahlchargen und deren Eigenschaften 


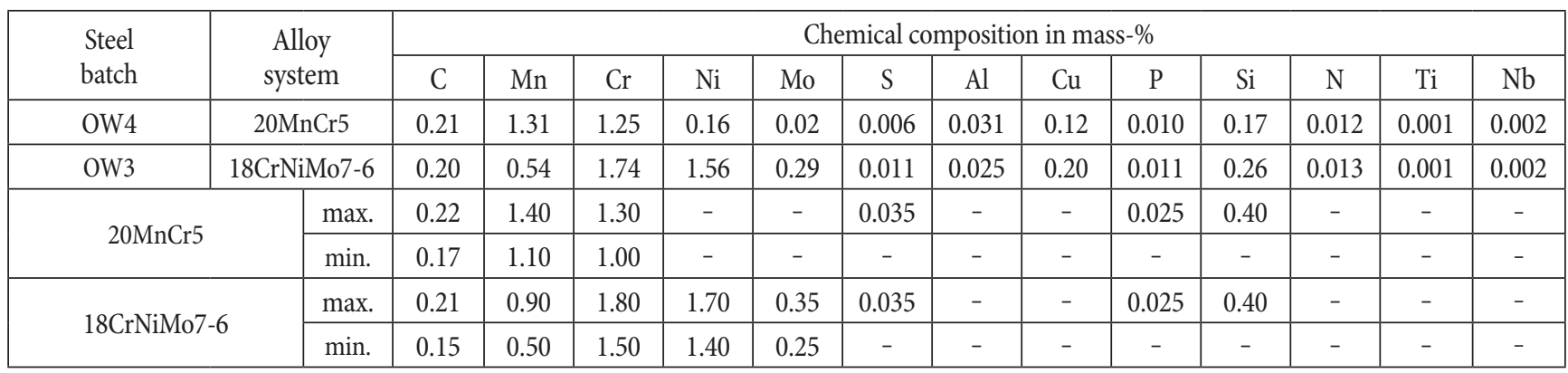

Table 3. Chemical analysis of steel batches and limits according to DIN EN ISO 683, Part 3 [24]

Tabelle 3. Chemische Analyse der Stahlchargen und Grenzwerte nach DIN EN ISO 683, Teil 3 [24]

$5: 1$ for continuous casting pursuant to ISO 6336, Part 5 [12]. The initial microstructure of the steel batch OW3 is banitic; that of OW4 ferritic-pearlitic with intercalated bainite. No further preheat treatment has taken place.

Table 3 and Table 4 show the chemical analysis and oxygen content data. Both steel batches are within the limits specified in DIN EN ISO 683, Part 3 [24]. Furthermore, both batches reveal oxygen contents below the maximum specified level of $25 \mathrm{ppm}$ pursuant to ISO 6336, Part 5 [12]; see Table 4.

The region of interest for the cleanliness inspections is positioned in the subsequent tooth root fillet area of the gear. Figure 1 illustrates the microscopic degree of cleanliness of the steel batches. The values are determined according to ISO 4967, Method A [25]. The lower the value, the higher the degree of cleanliness. Steel batch OW3 shows a value of above five, while that for batch OW4 is better at below 4. Both variants are below the threshold values for material quality ME based on ISO 4967, Method A [25] pursuant to Part 5 of ISO 6336 [12] for case-hardened wrought steels.

The prior austenite grain size pursuant to DIN EN ISO 643 [13] of the raw material of both steel batches is given in Table 5. Figure 2 shows the cumulative grain area fraction and the non-permitted area according to ISO 6336, Part 5 [12]. Both variants basically show fine grain. The grain size values according to DIN EN ISO 643 [13] are determined in the core region of the specimen and are very close to each other. However, some differences can be observed in the cumulative plot. All in all, steel batch OW3 shows a finer grain than steel batch OW4.

Fig. 1. Stacked bar diagram showing the degree of cleanliness pursuant to ISO 4967 Method A [25] of the steel batches investigated

Bild 1. Gestapeltes Balkendiagramm zur Darstellung des Reinheitsgrades nach ISO 4967 Methode A [25] der untersuchten Stahlchargen über dem Spezifikationswert von 5:1 für Strangguss nach ISO 6336, Teil 5 [12]. Das Ausgangsgefüge der Stahlcharge OW3 ist banitisch, das von OW4 ferritisch-perlitisch mit eingelagertem Bainit. Eine weitere Vorwärmbehandlung hat nicht stattgefunden.

Tabelle 3 und Tabelle 4 zeigen die Daten der chemischen Analyse und des Sauerstoffgehalts. Beide Stahlchargen liegen innerhalb der in DIN EN ISO 683, Teil 3 [24] festgelegten Grenzwerte. Darüber hinaus weisen beide Chargen Sauerstoffgehalte auf, die unter dem spezifizierten Höchstwert von 25 ppm nach ISO 6336, Teil 5 [12] liegen; siehe Tabelle 4.

Der Bereich für die Reinheitsgradbestimmung liegt im Bereich der späteren Zahnfußrundung des Zahnrades. Bild 1 zeigt den mikroskopischen Reinheitsgrad der Stahlchargen. Die Werte werden nach ISO 4967, Methode A [25] ermittelt. Je niedriger der Wert, desto höher ist der Reinheitsgrad. Die Stahlcharge OW3 weist einen Wert von über 5 auf, während der Wert für die Charge OW4 mit unter 4 besser ist. Beide Varianten liegen unter den Grenzwerten für die Werkstoffqualität ME nach ISO 4967, Methode A [25] gemäß Teil 5 der ISO 6336 [12] für einsatzgehärtete Einsatzstähle.

Die ehemalige Austenitkorngröße nach DIN EN ISO 643 [13] des Rohmaterials beider Stahlchargen ist in Tabelle 5 angegeben. Bild 2 zeigt den kumulativen Kornflächenanteil und die nicht zulässige Fläche nach ISO 6336, Teil 5 [12]. Beide Varianten weisen grundsätzlich Feinkorn auf. Die Korngrößenwerte nach DIN EN ISO 643 [13] werden im Kernbereich des Probekörpers ermittelt und liegen sehr nahe beieinander. In der Summenkurve sind jedoch einige Unterschiede $\mathrm{zu}$ erkennen. Insgesamt zeigt die Stahlcharge OW3 ein feineres Korn als die Stahlcharge OW4.

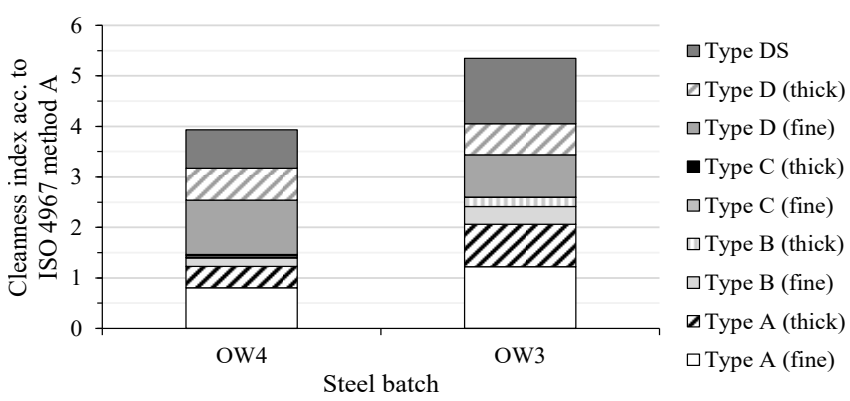




\begin{tabular}{|c|c|c|}
\hline & OW4 & OW3 \\
\hline Ototal in ppm & 9 & 14 \\
\hline
\end{tabular}

Table 4. Total oxygen content of the steel batches

Tabelle 4. Gesamtsauerstoffgehalt der Stahlchargen

There was no possibility to use the gas carburizing furnaces in the production lanes. Therefore, laboratory powder carburizing furnaces are used for the heat treatment experiments. Nevertheless, the results of the powder carburizing used can be compared with the gas carburizing process, though different parameters during that process must be chosen. The investigations are performed on a quarter disk (diameter: see Table 2; thickness: $20 \mathrm{~mm}$ ) of each material, using a special carbon box for the carburizing process. The specimens are wired and tied together such that they can be both removed from the carbon box and quenched simultaneously. To ensure that they are surrounded by the carbon mixture, they are placed in a special carbon box. A type $\mathrm{K}$ temperature sensor is used for the investigations. The carbon box is of the dimensions $205 \times 180 \times 130 \mathrm{~mm}$ and is filled with a powder mixture for carburizing. During heat treatment, the lid of the box is closed and sealed with ceramic fibers. A mild-acting quenching oil with a temperature of approximately $30^{\circ} \mathrm{C}$ is used.

To enable metallographic analysis, the specimens are embedded using a warm embedding press after the heat treatment and polished in five stages. The core hardness is determined using the Brinell method HBW 2.5/187.5. Conversion from Brinell to Rockwell hardness is in line with DIN EN ISO 18265 [26]. Vickers method HV1 is used for the hardness depth profile. The grain size is determined by the "Bechet-Beaujard" method by etching with aqueous, saturated picric acid solution pursuant to DIN EN ISO 643 [13]. The grain size is evaluated with PixelFerber [27] software.

\section{Procedure}

Table 6 shows the basic parameters for the case-hardening process. After preheating to $500^{\circ} \mathrm{C}$, a first soaking level is set to guarantee a sufficient soaking time and to enable a uniform temperature level of approximately 750 to $810^{\circ} \mathrm{C}$ in the carbon box far

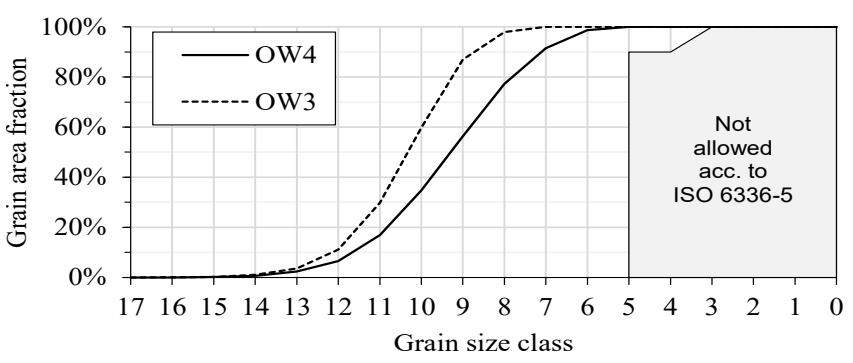

\begin{tabular}{|c|c|c|}
\hline Steel batch & OW4 & OW3 \\
\hline Grain size (chord length) & 9.86 & 10.68 \\
\hline
\end{tabular}

Table 5. Grain size of the raw material pursuant to DIN EN ISO 643 [13]

Tabelle 5. Korngröße des Rohmaterials nach DIN EN ISO 643 [13]

Es gab keine Möglichkeit, Gasaufkohlungsöfen in der Produktionslinie zu verwenden. Daher wurden für die Wärmebehandlungsversuche Labor-Pulveraufkohlungsöfen verwendet. Dennoch können die Ergebnisse der Pulveraufkohlung mit denen der Gasaufkohlung verglichen werden, auch wenn bei diesem Verfahren andere Parameter gewählt werden müssen. Die Untersuchungen werden an einer Viertelscheibe (Durchmesser: siehe Tabelle 2; Dicke: $20 \mathrm{~mm}$ ) jedes Werkstoffs unter Verwendung eines speziellen Kohlungskastens für den Aufkohlungsprozess durchgeführt. Die Proben sind so miteinander verdrahtet und verbunden, dass sie gleichzeitig dem Kohlungskasten entnommen und abgeschreckt werden können. Um sicherzustellen, dass sie von der Kohlenstoffmischung umgeben sind, werden sie in einen speziellen Kohlungskasten gelegt. Für die Untersuchungen wird ein Temperaturfühler vom Typ K verwendet. Der Kohlungskasten hat die Abmessungen $205 \times 180 \times 130 \mathrm{~mm}$ und ist mit einer Pulvermischung zum Aufkohlen gefüllt. Während der Wärmebehandlung wird der Deckel des Kastens geschlossen und mit Keramikfasern abgedichtet. Es wird ein mild wirkendes Abschrecköl mit einer Temperatur von etwa $30^{\circ} \mathrm{C}$ verwendet.

Für die metallographische Untersuchung werden die Proben nach der Wärmebehandlung mit einer Warmeinbettpresse eingebettet und in fünf Stufen poliert. Die Kernhärte wird nach dem Brinell-Verfahren HBW 2,5/187,5 bestimmt. Die Umrechnung von Brinell- in Rockwellhärte erfolgt nach DIN EN ISO 18265 [26]. Für den Härtetiefenverlauf wird das Vickers-Verfahren HV1 verwendet. Die Korngröße wird nach der "Bechet-Beaujard"-Methode durch Ätzen mit wässriger, gesättigter Pikrinsäurelösung nach DIN EN ISO 643 [13] bestimmt. Die Auswertung der Korngröße erfolgt mit der Software PixelFerber [27].

\section{Verfahren}

Tabelle 6 zeigt die grundlegenden Parameter für den Einsatzhärtungsprozess. Nach dem Vorwärmen auf $500{ }^{\circ} \mathrm{C}$ wird eine erste Haltestufe eingestellt, um eine ausreichende Haltezeit zu gewährleisten und ein gleichmäßiges Temperaturniveau von etwa 750 bis $810^{\circ} \mathrm{C}$

Fig. 2. Cumulative grain area fraction in the core region of the raw material of the steel batches

Bild 2. Kumulierter Kornflächenanteil im Kernbereich des Rohmaterials der Stahlchargen 
Table 6. Basic parameters for the case-hardening process investigation

Tabelle 6. Basisparameter für die Untersuchung des Einsatzhärtungsprozesses

\begin{tabular}{|c|c|c|c|}
\hline \multicolumn{2}{|c|}{ Process step } & Duration in min & Temperature in ${ }^{\circ} \mathrm{C}$ \\
\hline Heating & Equalization & 300 & 500 \\
\hline Carburization & Carburization & 360 & 950 \\
\hline \multirow{2}{*}{ Hardening } & Lowering to hardening temperature & 90 & 950 to 870 \\
\cline { 2 - 4 } & Hardening In oil \\
\hline Quenching & \multicolumn{2}{|c|}{} \\
\hline
\end{tabular}

below the transformation temperature. This enables better comparability between the individual heating rates in the temperature range in which the phase transformation from $\alpha$ to $\gamma$ takes place. Of course, the material is already being tempered at this first soaking level. The carburization temperature is $950^{\circ} \mathrm{C}$.

Three test series are investigated with different parameter variations:

- 'Heating rate' variation: Continuous heating with a constant temperature increase at heating rates of $6 \mathrm{~K} / \mathrm{min}, 3 \mathrm{~K} / \mathrm{min}$, $1 \mathrm{~K} / \mathrm{min}$ followed by a carburization time of $360 \mathrm{~min}$ at $950{ }^{\circ} \mathrm{C}$ (see Table 7).

- 'Equal furnace duration time' variation: Constant heating rates of $6 \mathrm{~K} / \mathrm{min}, 3 \mathrm{~K} / \mathrm{min}, 1 \mathrm{~K} / \mathrm{min}$ followed by a carburization time adjusted to attain equal total furnace duration times (see Table 8).

- 'Soaking temperature' variation: Heating rate of $6 \mathrm{~K} / \mathrm{min}$ interrupted by different additional soaking levels at $750{ }^{\circ} \mathrm{C}, 780^{\circ} \mathrm{C}$, and $810^{\circ} \mathrm{C}$, followed by carburization for $360 \mathrm{~min}$ at $950^{\circ} \mathrm{C}$ (see Table 9).

Table 7 contains an overview of the heating rate variation. The rate is varied by setting to 6,3 or $1 \mathrm{~K} / \mathrm{min}$, respectively. Variation $6 \mathrm{R}$ is the reference used throughout this paper. The remaining case-hardening parameters are in line with Table 6. Overall, six variants are examined. The temperature-time sequences of the specimens are shown in Figure 3.

Table 8 shows the equal furnace duration time variation. An equal furnace duration time is specified, which is achieved by modifying the heating rate and adjusting the carburizing time. This requires a soaking time of $285 \mathrm{~min}$ for a heating rate of $3 \mathrm{~K} / \mathrm{min}$. The temperature-time sequences are shown in Figure 4.

Finally, in the soaking temperature variation, an additional soaking level is inserted during the heating phase (see Table 9). Three

Table 7. 'Heating rate variation' - Variation of the heating step with different heating rates

Tabelle 7. „Heizratenvariation" - Variation des Aufheizschrittes bei unterschiedlichen Aufheizraten

Table 8. 'Equal furnace duration time' variation - Variation of the heating step with different heating rates and carburizing temperature adjusted for an equal furnace duration time

Tabelle 8. „Gleiche Ofenverweildauer" - Variation des Aufheizschrittes mit unterschiedlichen Aufheizraten und Aufkohlungstemperatur angepasst an eine gleiche Ofendauer im Kohlungskasten weit unterhalb der Umwandlungstemperatur zu ermöglichen. Dies gewährleistet eine bessere Vergleichbarkeit der einzelnen Heizraten in dem Temperaturbereich, in dem die Phasenumwandlung von $\alpha \mathrm{zu} \gamma$ stattfindet. Natürlich wird das Material bereits auf dieser ersten Haltestufe angelassen. Die Aufkohlungstemperatur beträgt $950^{\circ} \mathrm{C}$.

Es werden drei Versuchsreihen mit unterschiedlichen Parametervariationen untersucht:

- Variation der „Heizrate": Kontinuierliches Aufheizen mit konstantem Temperaturanstieg bei Aufheizraten von $6 \mathrm{~K} / \mathrm{min}$, $3 \mathrm{~K} / \mathrm{min}, 1 \mathrm{~K} / \mathrm{min}$ gefolgt von einer Aufkohlungszeit von $360 \mathrm{~min}$ bei $950^{\circ} \mathrm{C}$ (siehe Tabelle 7).

-Variante „Gleiche Ofendauer": Konstante Aufheizraten von $6 \mathrm{~K} / \mathrm{min}, 3 \mathrm{~K} / \mathrm{min}, 1 \mathrm{~K} / \mathrm{min}$, gefolgt von einer Aufkohlungszeit, die so eingestellt ist, dass die Ofenverweildauer gleich ist (siehe Tabelle 8).

- Variation der „Haltetemperatur": Aufheizgeschwindigkeit von $6 \mathrm{~K} / \mathrm{min}$, unterbrochen durch verschiedene zusätzliche Haltestufen bei $750^{\circ} \mathrm{C}, 780^{\circ} \mathrm{C}$ und $810^{\circ} \mathrm{C}$, gefolgt von einer Aufkohlung von $360 \mathrm{~min}$ bei $950^{\circ} \mathrm{C}$ (siehe Tabelle 9).

Tabelle 7 enthält eine Übersicht über die Variation der Aufheizrate. Die Rate wird durch Einstellung auf 6, 3 bzw. $1 \mathrm{~K} / \mathrm{min}$ variiert. Die Variation 6R wird in dieser Veröffentlichung als Referenz verwendet. Die übrigen Einsatzhärtungsparameter entsprechen denen der Tabelle 6. Insgesamt werden sechs Varianten untersucht. Die TemperaturZeit-Verläufe der Proben sind in Bild 3 dargestellt.

Tabelle 8 zeigt die Variation der gleichen Ofenverweildauer. Es wird eine gleiche Ofenverweildauer vorgegeben, die durch Änderung der Aufheizgeschwindigkeit und Anpassung der Aufkohlungszeit erreicht wird. Dies erfordert eine Durchwärmungszeit von 285 min bei einer Aufheizrate von $3 \mathrm{~K} / \mathrm{min}$. Die Temperatur-ZeitVerläufe sind in Bild 4 dargestellt.

Schließlich wird bei der Variation der Haltetemperatur eine zusätzliche Haltestufe während der Aufwärmphase eingefügt (sie-

\begin{tabular}{|c|c|c|c|}
\hline \multirow{2}{*}{ Variation } & Heating rate & \multicolumn{2}{|c|}{ Variants per steel batch } \\
& in K/min & OW $\underline{\mathbf{4}}$ & OW $\underline{\mathbf{3}}$ \\
\hline 6R (reference) & 6 & $\underline{\mathbf{4}} 6 \mathrm{R}$ & $\underline{\mathbf{3}} 6 \mathrm{R}$ \\
\hline 3R & 3 & $\underline{\mathbf{4}} 3 \mathrm{R}$ & $\underline{\mathbf{3}} 3 \mathrm{R}$ \\
\hline 1R & 1 & $\underline{\mathbf{4}} 1 \mathrm{R}$ & $\underline{\mathbf{3}} 1 \mathrm{R}$ \\
\hline
\end{tabular}

\begin{tabular}{|c|c|c|c|c|}
\hline Variation & Heating rate & Soaking time & \multicolumn{2}{|c|}{ Steel batch } \\
in K/min & in min & OW $\underline{\mathbf{4}}$ & OW $\underline{\mathbf{3}}$ \\
\hline $3 \mathrm{~K}$ & 3 & 285 & $\underline{\mathbf{4}} 3 \mathrm{~K}$ & $\underline{\mathbf{3}} 3 \mathrm{~K}$ \\
\hline $1 \mathrm{~K}$ & 1 & 0 & $\underline{\mathbf{4}} 1 \mathrm{~K}$ & $\underline{\mathbf{3}} 1 \mathrm{~K}$ \\
\hline
\end{tabular}




\begin{tabular}{|c|c|c|c|c|c|}
\hline \multirow{2}{*}{ Variation } & \multirow{2}{*}{$\begin{array}{l}\text { Heating rate } \\
\text { in } \mathrm{K} / \mathrm{min}\end{array}$} & \multicolumn{2}{|c|}{ Soaking level } & \multicolumn{2}{|c|}{ Steel batch } \\
\hline & & Temperature in ${ }^{\circ} \mathrm{C}$ & Duration in min & OW $\underline{4}$ & OW $\underline{3}$ \\
\hline 65 & \multirow{3}{*}{6} & 750 & \multirow{3}{*}{180} & $\underline{4} 65$ & $\underline{3} 65$ \\
\hline 68 & & 780 & & $\underline{4} 68$ & $\underline{3} 68$ \\
\hline 61 & & 810 & & $\underline{4} 61$ & $\underline{3} 61$ \\
\hline
\end{tabular}

Table 9. 'Soaking temperature' variation - Variation of the heating step with different additional soaking levels in the transformation zone

Tabelle 9. Variation „Haltetemperatur“ - Variation des Aufwärmschrittes mit verschiedenen zusätzlichen Haltestufen in der Umwandlungszone

soaking levels are defined at $750^{\circ} \mathrm{C}, 780^{\circ} \mathrm{C}$, and $810^{\circ} \mathrm{C}$, respectively. The duration of the soaking level is set to 180 minutes for all three parameters. All other case-hardening parameters shown in Table 6 are not affected. The temperature-time sequences of the specimens are shown in Figure 5.

\section{Effects of heat treatment process parame- ter variations on case-hardening depth, surface hardness, and core hardness}

Table 10 presents the case-hardening depths and the surface and core hardness numbers achieved by each heating rate variation. Core hardness values range between 421 and 435 HBW. No influ-
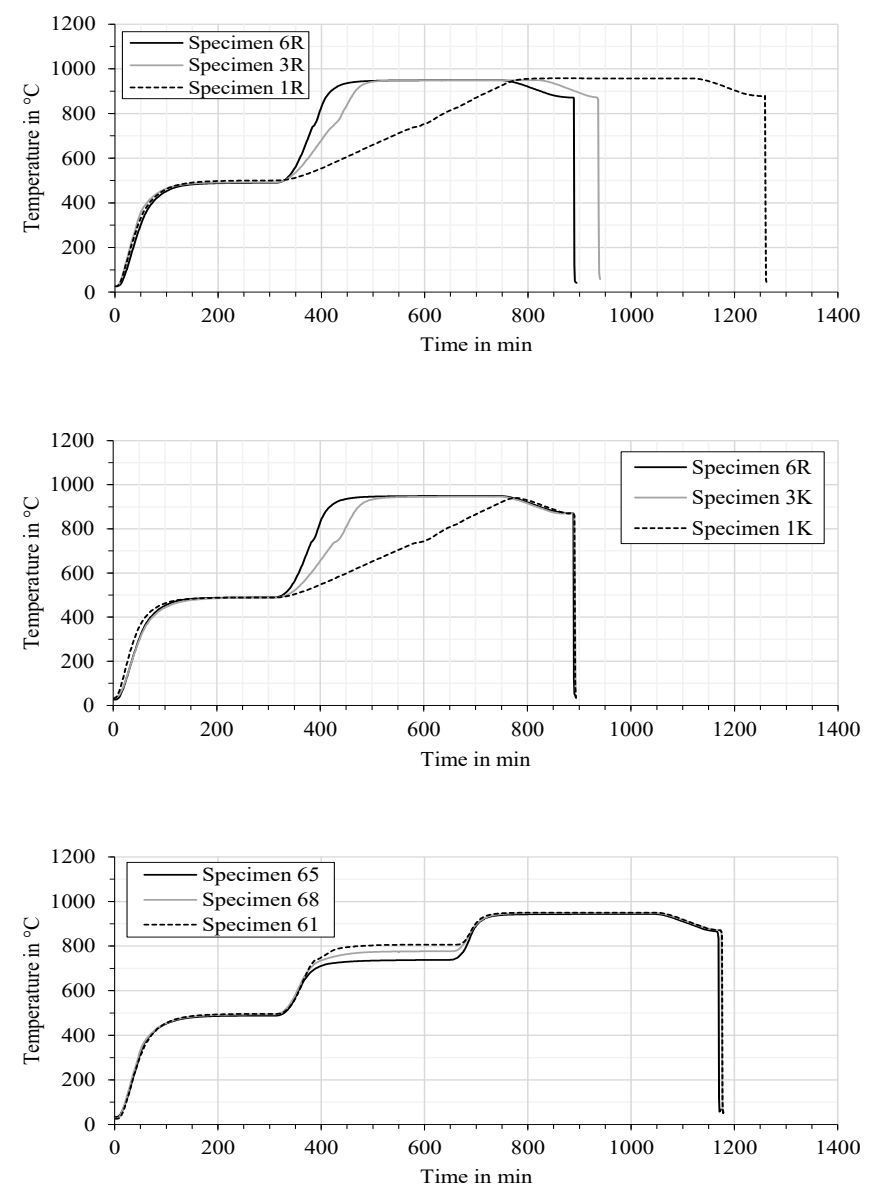

Fig. 5. 'Soaking temperature' variation - temperature-time sequence of the specimen (thermocouple in specimen)

Bild 5. Verlauf der „Haltetemperatur“ - Temperatur-Zeit-Verlauf der Probe (Thermoelement in der Probe) he Tabelle 9). Es werden drei Haltestufen bei $750{ }^{\circ} \mathrm{C}, 780^{\circ} \mathrm{C}$ bzw. $810^{\circ} \mathrm{C}$ definiert. Die Dauer der Haltestufen wird für alle drei $\mathrm{Pa}$ rameter auf 180 Minuten festgelegt. Alle anderen in Tabelle 6 aufgeführten Einsatzhärtungsparameter werden nicht beeinflusst. Die Temperatur-Zeit-Verläufe der Proben sind in Bild 5 dargestellt.

\section{Auswirkungen von Variationen der Wärmebehandlungsparameter auf Einsatzhärtungstiefe, Oberflächenhärte und Kernhärte}

Tabelle 10 zeigt die Einsatzhärtungstiefen sowie die Oberflächenund Kernhärte, die bei den einzelnen Heizratenvariationen erreicht wurden. Die Kernhärtewerte liegen zwischen 421 und 435 HBW.

Fig. 3. 'Heating rate' variation - temperature-time sequence of the specimen (thermocouple in specimen)

Bild 3. Verlauf der „Aufheizrate“-Temperatur-Zeit-Verlauf der Probe (Thermoelement in der Probe)

Fig. 4. 'Equal furnace duration time' variation - temperature-time sequence of the specimen (thermocouple in specimen)

Bild 4. Variation der "Gleichen Ofenverweildauer" - Temperatur-ZeitVerlauf der Probe (Thermoelement in der Probe) 
Table 10. 'Heating rate' variation - case-hardening depths and core hardnesses

Tabelle 10. Variation „Aufheizrate" - Einsatzhärtungstiefen und Kernhärten

\begin{tabular}{|c|c|c|c|c|c|c|c|}
\hline \multirow{2}{*}{\multicolumn{2}{|c|}{$\begin{array}{c}\text { Steel batch } \\
\text { Variant } \\
\end{array}$}} & \multicolumn{3}{|c|}{ OW4 } & \multicolumn{3}{|c|}{ OW3 } \\
\hline & & $46 \mathrm{R}$ & $43 \mathrm{R}$ & $41 \mathrm{R}$ & $36 \mathrm{R}$ & $33 \mathrm{R}$ & $31 \mathrm{R}$ \\
\hline \multicolumn{2}{|c|}{$\mathrm{CHD}_{550 \mathrm{HV} 1}$ in $\mathrm{mm}$} & 1.29 & 1.33 & 1.28 & 1.13 & 1.17 & 1.16 \\
\hline \multicolumn{2}{|c|}{ Surface hardness in HV1 } & 733 & 728 & 712 & 699 & 704 & 707 \\
\hline \multirow{2}{*}{ Core hardness } & in HBW & 431 & 435 & 421 & 435 & 424 & 423 \\
\hline & in $\mathrm{HRC}$ & 45.3 & 46.1 & 44.5 & 46.1 & 45.3 & 44.5 \\
\hline
\end{tabular}

ence on core hardness is evident at any of the applied heating rates. Figure 6 and Figure 7 show the hardness depth profiles of both steel batches. A similar CHD can be achieved for both materials with the heating rates $6 \mathrm{R}, 3 \mathrm{R}$ and $1 \mathrm{R}$. The $\mathrm{CHD}_{550 \mathrm{HV} 1}$ values in this case are approximately $1.30 \mathrm{~mm}$ for steel batch OW4 and $1.15 \mathrm{~mm}$ for steel batch OW3.

Investigations of the equal furnace duration time variation reveal (significantly) lower $\mathrm{CHD}_{550 \mathrm{HV} 1}$ values for both steel batches; see Table 11 . The lowest values are for the $1 \mathrm{~K}$ variants. The core hardness values are in the range of 417 to $425 \mathrm{HBW}$. The highest surface hardness values for both steel batches are attained by the $3 \mathrm{~K}$ variation. The $1 \mathrm{~K}$ variation shows the second-highest value for steel batch OW4 and the lowest value for steel batch OW3. The variations $6 \mathrm{R}, 3 \mathrm{R}$ and $1 \mathrm{R}$ result in similar values for both steel batches.

Table 12 shows the values for case-hardening depth, surface hardness and core hardness for the soaking temperature variation. The various soaking temperatures have virtually no influence on either surface hardness, core hardness or case-hardening depth. The core hardness numbers are between 418 and 438 HBW. The case-hardening depth values are approximately $1.20 \mathrm{~mm}$ for steel batch

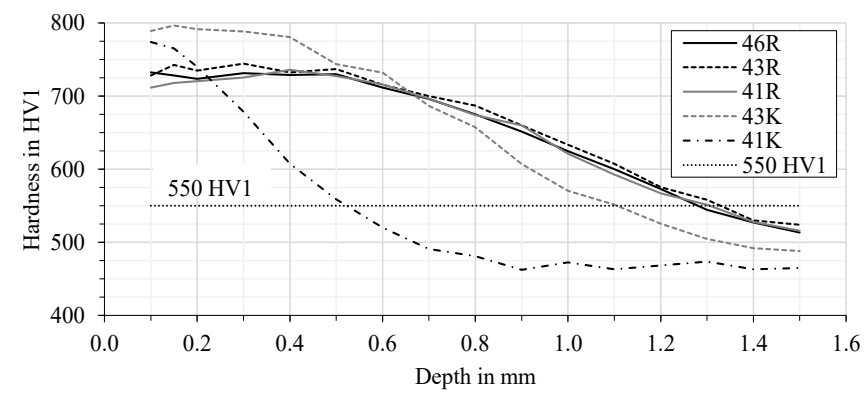

Fig. 6. 'Heating rate' and 'equal furnace duration time' variations - hardness depth profiles of steel batch OW4

Bild 6. Variation der „Aufheizrate" und der ,gleichen Ofenverweildauer" Härtetiefenverläufe der Stahlcharge OW4
Bei keiner der angewandten Aufheizraten ist ein Einfluss auf die Kernhärte erkennbar. Bild 6 und Bild 7 zeigen die Härtetiefenverläufe der beiden Stahlchargen. Mit den Aufheizraten 6R, 3R und $1 \mathrm{R}$ kann für beide Werkstoffe eine ähnliche CHD erreicht werden. Die $\mathrm{CHD}_{550 \mathrm{HV} 1}$-Werte liegen in diesem Fall bei etwa $1,30 \mathrm{~mm}$ für die Stahlcharge OW4 und 1,15 mm für die Stahlcharge OW3.

Untersuchungen der gleichen Ofenverweildauer-Variation zeigen (deutlich) niedrigere $\mathrm{CHD}_{550 \mathrm{HV} 1}$-Werte für beide Stahlchargen, siehe Tabelle 11. Die niedrigsten Werte sind bei den 1K-Varianten zu finden. Die Kernhärtewerte liegen im Bereich von 417 bis 425 HBW. Die höchsten Oberflächenhärtewerte für beide Stahlchargen werden von der 3K-Variante erreicht. Die 1K-Variante zeigt den zweithöchsten Wert für die Stahlcharge OW4 und den niedrigsten Wert für die Stahlcharge OW3. Die Varianten 6R, 3R und $1 \mathrm{R}$ ergeben ähnliche Werte für beide Stahlchargen.

Tabelle 12 zeigt die Werte für die Einsatzhärtungstiefe, die Oberflächenhärte und die Kernhärte für die Variation der Haltetemperatur. Die verschiedenen Haltetemperaturen haben praktisch keinen Einfluss auf die Oberflächenhärte, die Kernhärte und die Einsatzhärtetiefe. Die Werte für die Kernhärte liegen zwischen 418 und 438 HBW. Die Werte für die Einsatzhärtungstiefe liegen

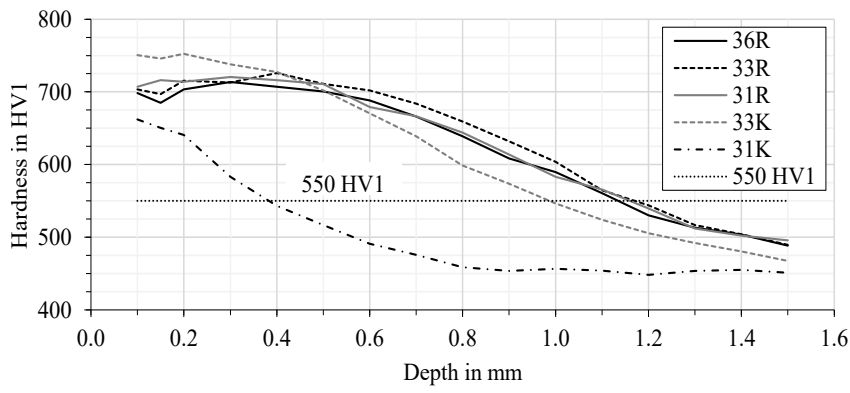

Fig. 7. 'Heating rate' and 'equal furnace duration time' variations - hardness depth profiles of steel batch OW3

Bild 7. Variationen der „Aufheizrate" und der „gleichen Ofenverweildauer" Härtetiefenverläufe der Stahlcharge OW3
Table 11. 'Equal furnace duration time' variation - case-hardening depths and core hardnesses

Tabelle 11. Variation „Gleiche Ofenverweildauer" - Einsatzhärtungstiefen und Kernhärten

\begin{tabular}{|c|c|c|c|c|c|}
\hline \multirow{2}{*}{\multicolumn{2}{|c|}{$\begin{array}{c}\text { Steel batch } \\
\text { Variant }\end{array}$}} & \multicolumn{2}{|c|}{ OW4 } & \multicolumn{2}{|c|}{ OW3 } \\
\hline & & $43 \mathrm{~K}$ & $41 \mathrm{~K}$ & $33 \mathrm{~K}$ & $31 \mathrm{~K}$ \\
\hline \multicolumn{2}{|c|}{$\mathrm{CHD}_{550 \mathrm{HV} 1}$ in $\mathrm{mm}$} & 1.11 & 0.52 & 0.99 & 0.38 \\
\hline \multicolumn{2}{|c|}{ Surface hardness in HV1 } & 789 & 774 & 751 & 662 \\
\hline \multirow{2}{*}{ Core hardness } & in HBW & 417 & 425 & 424 & 423 \\
\hline & in HRC & 44.5 & 45.3 & 45.3 & 44.5 \\
\hline
\end{tabular}




\begin{tabular}{|c|c|c|c|c|c|c|c|}
\hline \multirow{2}{*}{\multicolumn{2}{|c|}{$\begin{array}{c}\text { Steel batch } \\
\text { Variant }\end{array}$}} & \multicolumn{3}{|c|}{ OW4 } & \multicolumn{3}{|c|}{ OW3 } \\
\hline & & 465 & 468 & 461 & 365 & 368 & 361 \\
\hline \multicolumn{2}{|c|}{$\mathrm{CHD}_{550 \mathrm{HV}}$ in $\mathrm{mm}$} & 1.26 & 1.20 & 1.20 & 0.97 & 0.99 & 1.08 \\
\hline \multicolumn{2}{|c|}{ Surface hardness in HV1 } & 754 & 724 & 742 & 699 & 713 & 698 \\
\hline \multirow{2}{*}{ Core hardness } & in HBW & 438 & 430 & 426 & 425 & 432 & 418 \\
\hline & in HRC & 46.1 & 45.3 & 45.3 & 45.3 & 45.3 & 44.5 \\
\hline
\end{tabular}

Table 12. 'Soaking temperature' variation - case-hardening depths and core hardnesses

Tabelle 12. Variation „Haltetemperatur" - Einsatzhärtungstiefen und Kernhärten

OW4 and approximately $1.00 \mathrm{~mm}$ for steel batch OW3. Figure 8 and Figure 9 show the hardness depth profiles for both steel batches. For steel batch OW4, the highest CHD value is reached at soaking temperature $750^{\circ} \mathrm{C}$ and the lowest at soaking temperatures $810^{\circ} \mathrm{C}$ (and $780^{\circ} \mathrm{C}$ ). For steel batch OW3, the trend is the opposite. The highest value is reached at soaking temperature $810^{\circ} \mathrm{C}$ and the lowest at soaking temperature $750{ }^{\circ} \mathrm{C}$. The surface hardness numbers range from 698 to $754 \mathrm{HV} 1$ and are all very similar for both steel batches.

\section{Effects of heat treatment process parameter variations on grain size}

In the following, the grain size values according to DIN EN ISO 643 [13] are determined in the core region of the specimens. Figure 10 and Figure 11 show the cumulative grain area fraction for the heating rate variation. The grain sizes of the variants at a continuous heating rate of $6 \mathrm{~K} / \mathrm{min}$ and $3 \mathrm{~K} / \mathrm{min}$ all comply with the specifications in ISO 6336, Part 5 [12]. The heating rate of $3 \mathrm{~K} / \mathrm{min}$ (variants 43R and 33R) leads to a slightly coarser grain in comparison to the reference variants $46 \mathrm{R}$ and $36 \mathrm{R}$, respectively. However, variants $41 \mathrm{R}$ and $31 \mathrm{R}$ (continuous heating rate of $1 \mathrm{~K} / \mathrm{min}$ ) display distinct grain coarsening and intersect the non-allowed area pursuant to ISO 6336, Part 5 [12]. Table 13 shows the microsections etched to grain size for variants $46 \mathrm{R}$ and $36 \mathrm{R}$ and the variants with the coarsest grain $41 \mathrm{R}$ and $31 \mathrm{R}$.

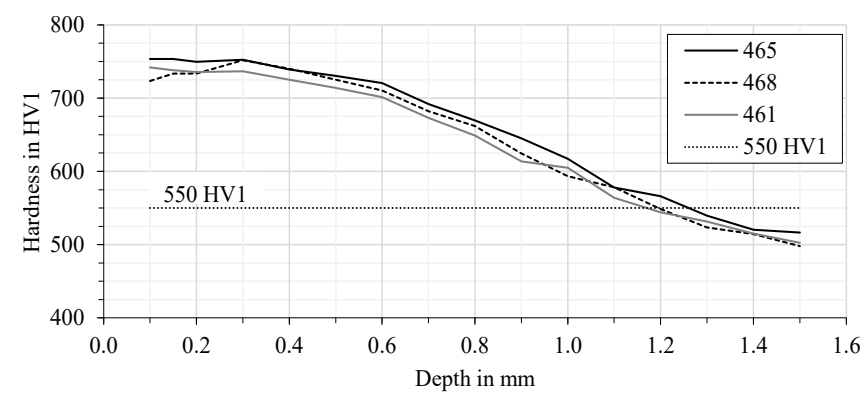

Fig. 8. 'Soaking temperature' variation - hardness depth profiles of steel batch OW4

Bild 8. Variation der „Einweichtemperatur“ - Härtetiefenverlauf der Stahlcharge OW4 bei ca. 1,20 mm für die Stahlcharge OW4 und ca. 1,00 mm für die Stahlcharge OW3. Bild 8 und Bild 9 zeigen die Härtetiefenverläufe für beide Stahlchargen. Für die Stahlcharge OW4 wird der höchste CHD-Wert bei einer Haltetemperatur von $750{ }^{\circ} \mathrm{C}$ und der niedrigste Wert bei einer Haltetemperatur von $810^{\circ} \mathrm{C}$ (und $780^{\circ} \mathrm{C}$ ) erreicht. Bei der Stahlcharge OW3 ist der Trend umgekehrt. Der höchste Wert wird bei einer Haltetemperatur von $810^{\circ} \mathrm{C}$ erreicht, der niedrigste bei einer Haltetemperatur von $750^{\circ} \mathrm{C}$. Die Werte für die Oberflächenhärte reichen von 698 bis $754 \mathrm{HV} 1$ und sind bei beiden Stahlchargen sehr ähnlich.

\section{Auswirkungen von Variationen der Wärmebehandlungsprozessparameter auf die Korngröße}

Im Folgenden werden die Korngrößenwerte nach DIN EN ISO 643 [13] im Kernbereich der Proben bestimmt. Bild 10 und Bild 11 zeigen den kumulativen Kornflächenanteil für die Heizratenvariation. Die Korngrößen der Varianten bei einer Aufheizrate von $6 \mathrm{~K} / \mathrm{min}$ und $3 \mathrm{~K} / \mathrm{min}$ entsprechen alle den Vorgaben der ISO 6336, Teil 5 [12]. Die Aufheizrate von 3 K/min (Varianten 43R und 33R) führt zu einem etwas gröberen Korn im Vergleich zu den Referenzvarianten 46R bzw. 36R. Die Varianten $41 \mathrm{R}$ und 31R (kontinuierliche Aufheizrate von $1 \mathrm{~K} / \mathrm{min}$ ) weisen dagegen eine deutliche Kornvergröberung auf und durchschneiden den nicht zulässigen Bereich nach ISO 6336, Teil 5 [12]. Tabelle 13 zeigt die auf Korngröße geätzten Schliffe für die Varianten $46 \mathrm{R}$ und $36 \mathrm{R}$ sowie die Varianten mit dem gröbsten Korn $41 \mathrm{R}$ und $31 \mathrm{R}$.

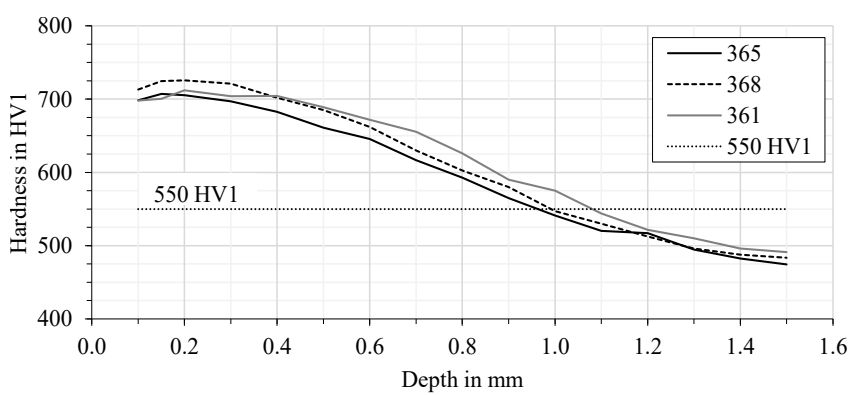

Fig. 9. 'Soaking temperature' variation - hardness depth profiles of steel batch OW3

Bild 9. Variation der „Haltetemperatur“ - Härtetiefenverlauf der Stahlcharge OW3 


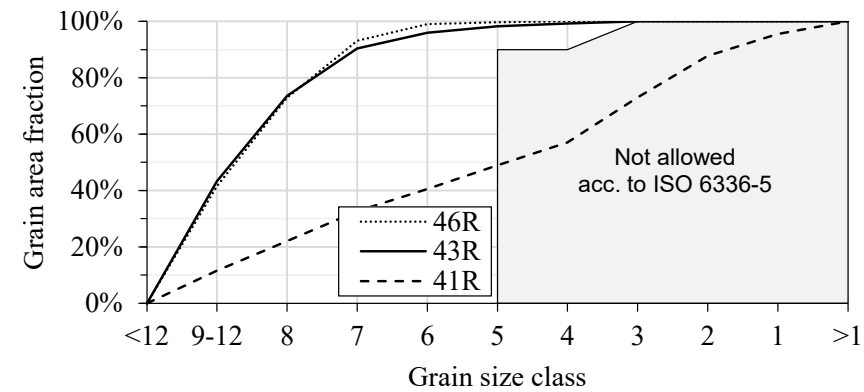

Fig. 10. 'Heating rate' variation - cumulative grain area fraction of steel batch OW4

Bild 10. Variation der „Aufheizrate“ - kumulativer Kornflächenanteil der Stahlcharge OW4

The cumulative grain area plots after the equal furnace duration time variation for steel batches OW4 and OW3 are given in Figure 12 and Figure 13. Even with the same furnace duration time, the specimens with a slower heating rate have coarser grains.

Figure 14 and Figure 15 show the cumulative grain area fraction after the soaking temperature variation of steel batches OW4 and OW3. The temperatures at the additional holding step are $750{ }^{\circ} \mathrm{C}$, $780^{\circ} \mathrm{C}$ and $810^{\circ} \mathrm{C}$, respectively. Table 14 shows the microsections etched to grain size. The worst grain size is achieved for both steel batches at a holding level of $780^{\circ} \mathrm{C}$.

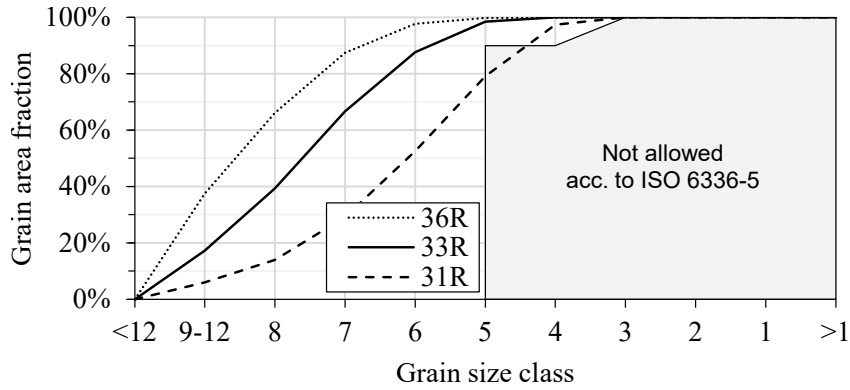

Fig. 11. 'Heating rate' variation - cumulative grain area fraction of steel batch OW3

Bild 11. Variation der „Aufheizrate“ - kumulativer Kornflächenanteil der Stahlcharge OW3

Die kumulativen Kornflächendiagramme nach der Variation der gleichen Ofenverweildauer für die Stahlchargen OW4 und OW3 sind in Bild 12 und Bild 13 dargestellt. Selbst bei gleicher Ofenverweildauer weisen die Proben mit langsamerer Aufheizgeschwindigkeit gröbere Körner auf.

Bild 14 und Bild 15 zeigen den kumulativen Kornflächenanteil nach der Variation der Haltetemperatur der Stahlchargen OW4 und OW3. Die Temperaturen beim zusätzlichen Halteschritt betragen $750^{\circ} \mathrm{C}, 780^{\circ} \mathrm{C}$ bzw. $810^{\circ} \mathrm{C}$. Tabelle 14 zeigt die auf Korngröße geätzten Mikroschliffe. Die schlechteste Korngröße wird für beide Stahlchargen bei einer Haltetemperatur von $780^{\circ} \mathrm{C}$ erreicht.
Table 13. 'Heating rate' variation - microsections etched to grain size of steel batches OW4 and OW3

Tabelle 13. Variation der „Aufheizrate“ - auf Korngröße geätzte Schliffe der Stahlchargen OW4 und OW3

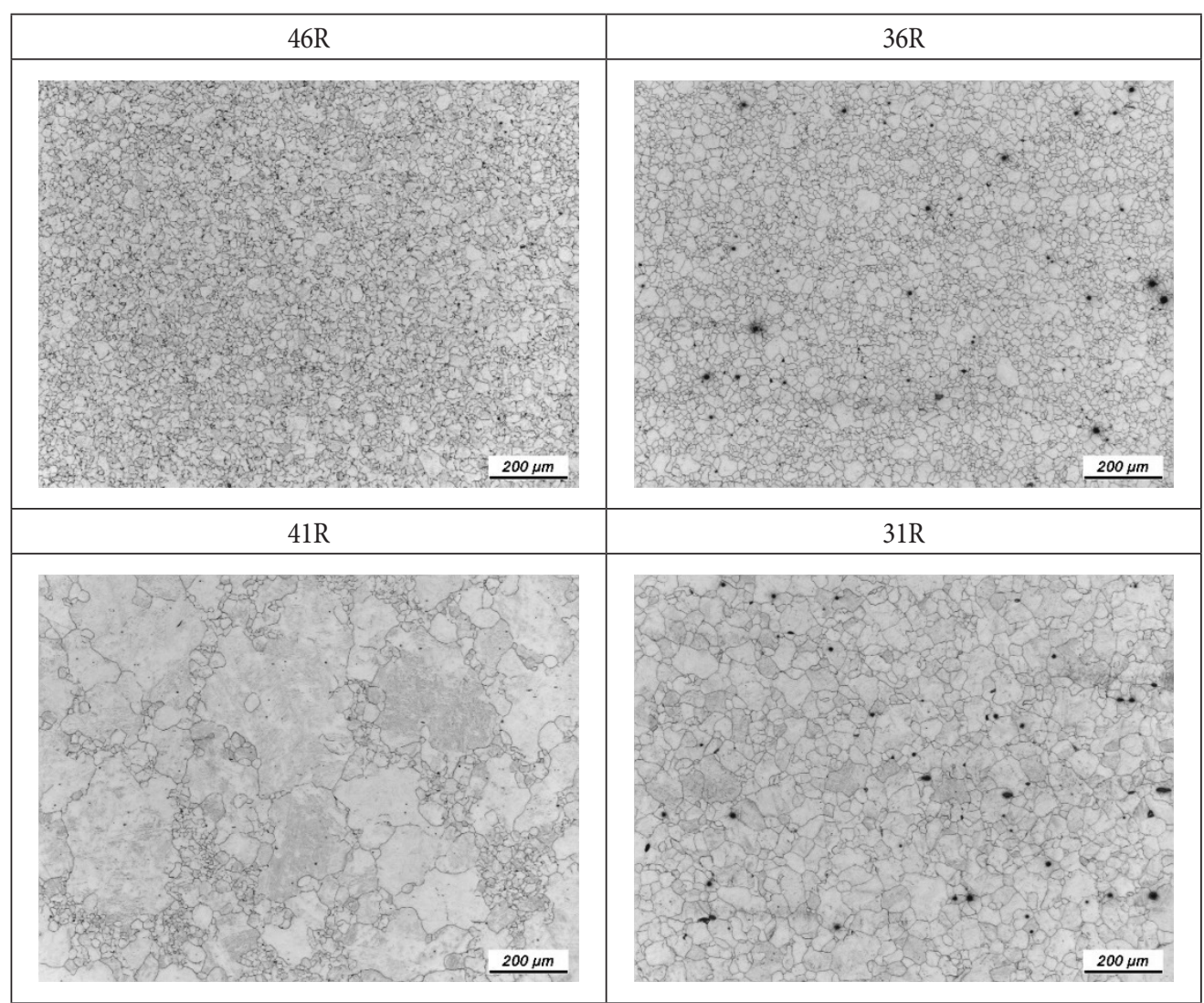




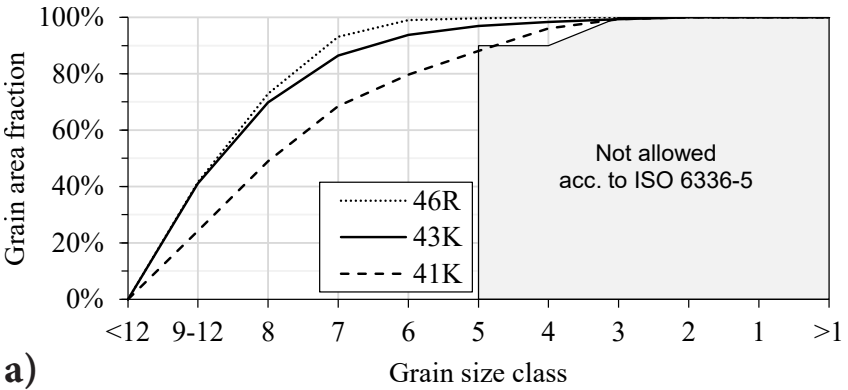

a)
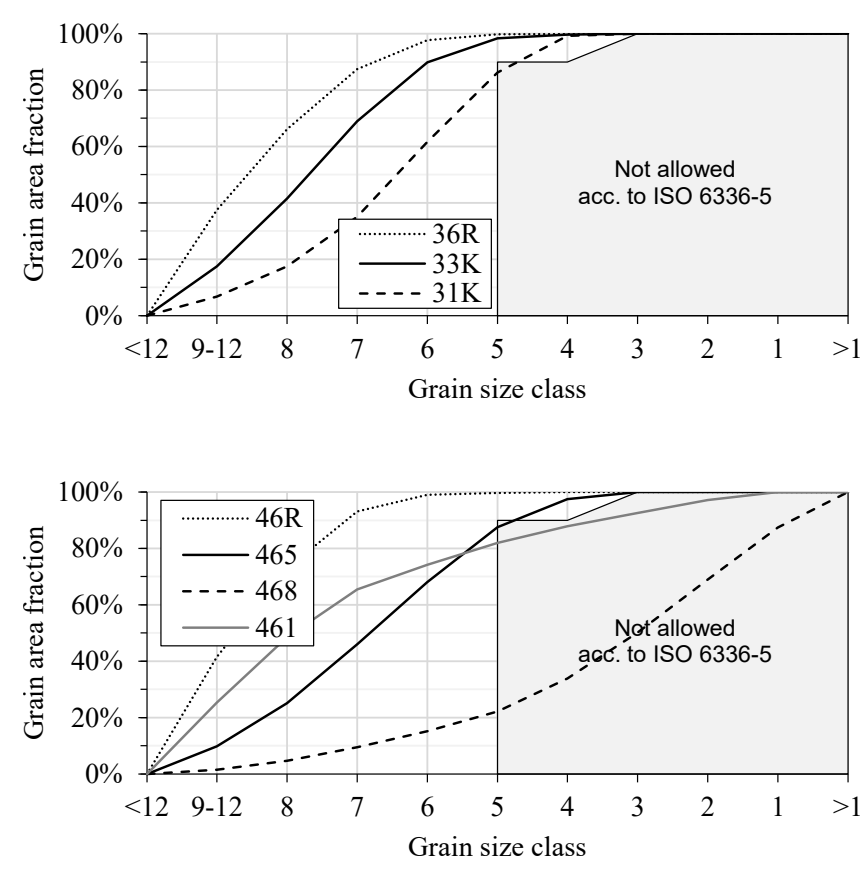

Fig. 14. 'Soaking temperature' variation - cumulative grain area fraction of steel batch OW4

Bild 14. Variation der „Haltetemperatur“ - kumulativer Kornflächenanteil der Stahlcharge OW4

\section{Comparison of results and conclusions}

This section compares and analyzes the results of the investigations. Variants 46R and 36R will serve as references (see Table 15). For the purpose of comparison, surface hardness, the case-hardening depth $\mathrm{CHD}_{550 \mathrm{HV} 1}$, and cumulative grain area will serve as evaluation criteria. It should be noted that carburizing was performed by a powder mixture in a carbon box. Thus, the results may display a higher degree of scatter than a controlled process in industrial practice. Core hardness is not used, because it is relatively similar for all variants and was consistently above the specification of 30 HRC pursuant to ISO 6336, Part 5 [12]. Surface hardness will also no longer be used, as it is primarily attained in the quenching process that following case-hardening. All surface hardness values are consistently within the specifications ( 660 to $800 \mathrm{HV}$ ) of ISO 6336, Part 5 [12].

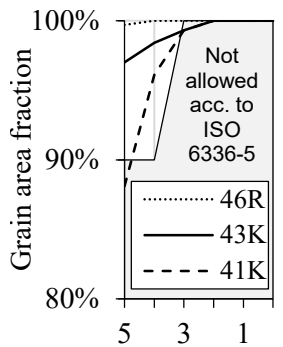

b) Grain size class
Fig. 12. 'Equal furnace duration time' variation a) overview of cumulative grain area fraction and b) detail view of cumulative grain area fraction in the range of grain size classes 5 to $>1$ of steel batch OW4

Bild 12. Verlauf der „Gleichen Ofenverweildauer“a) Übersicht des kumulativen Kornflächenanteils und b) Detailansicht des kumulativen Korn5 bis $>1$ der Stahlcharge OW4 flächenanteils im Bereich der Korngrößenklassen

Fig. 13. 'Equal furnace duration time' variation - cumulative grain area fraction of steel batch OW3

Bild 13. Verlauf der „Gleichen Ofenverweildauer“ - kumulativer Kornflächenanteil der Stahlcharge OW3

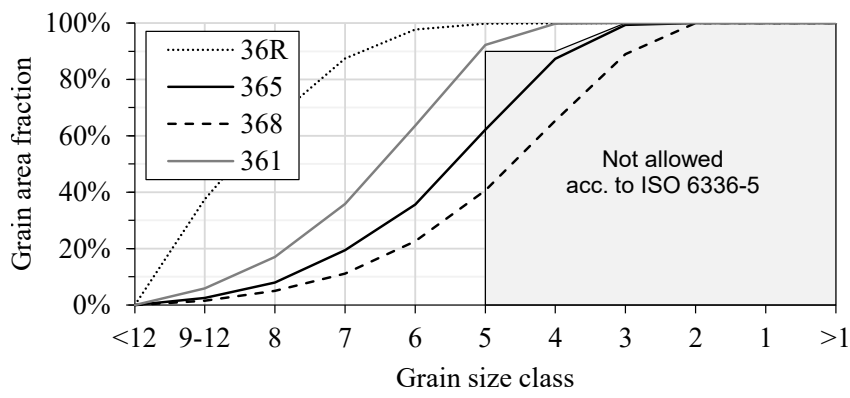

Fig. 15. 'Soaking temperature' variation - cumulative grain area fraction of steel batch OW3

Bild 15. Variation der „Haltetemperatur“ - kumulativer Kornflächenanteil der Stahlcharge OW3

\section{Vergleich der Ergebnisse und Schlussfolgerungen}

In diesem Abschnitt werden die Ergebnisse der Untersuchungen verglichen und analysiert. Die Varianten 46R und 36R dienen als Referenz (siehe Tabelle 15). Zum Vergleich werden die Oberflächenhärte, die Einsatzhärtetiefe $\mathrm{CHD}_{550 \mathrm{HV} 1}$ und die kumulierte Kornfläche als Bewertungskriterien herangezogen. Es ist zu beachten, dass die Aufkohlung mit einer Pulvermischung in einem Kohlungskasten durchgeführt wurde. Daher können die Ergebnisse einen höheren Grad an Streuung aufweisen als bei einem kontrollierten Prozess in der industriellen Praxis. Die Kernhärte wird nicht verwendet, da sie bei allen Varianten relativ ähnlich ist und durchweg über der Spezifikation von 30 HRC gemäß ISO 6336, Teil 5 [12] lag. Die Oberflächenhärte wird ebenfalls nicht mehr verwendet, da sie in erster Linie durch das Abschrecken nach dem Einsatzhärten erreicht wird. Alle Oberflächenhärtewerte liegen 
Table 14. Variants 468 and 368 of the 'soaking temperature' variation - microsections etched to grain size

Tabelle 14. Varianten 468 und 368 derVariation "Haltetemperatur" - auf Korngröße geätzte Schliffbilder

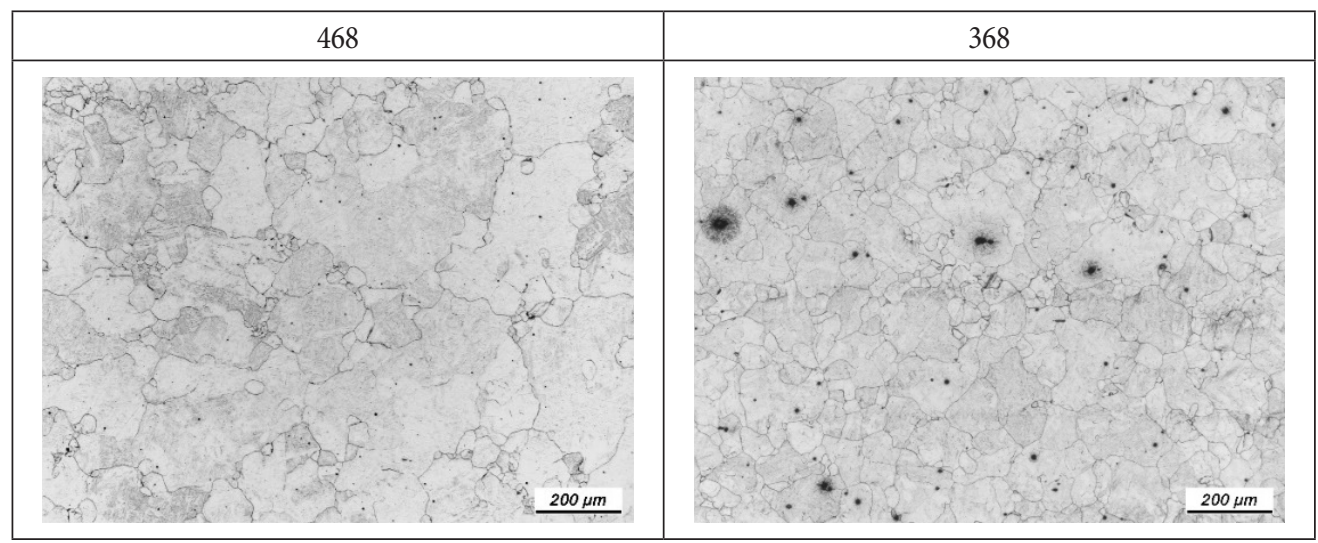

Table 15. Properties of the reference variants $46 R$ and $36 R$ (heating rate $6 \mathrm{~K} / \mathrm{min}$ )

Tabelle 15. Eigenschaften der Referenzvarianten 46R und 36R (Aufheizrate $6 \mathrm{~K} / \mathrm{min}$ )

\begin{tabular}{|c|c|c|c|}
\hline \multirow{2}{*}{ Variant } & \multicolumn{3}{|c|}{ Properties } \\
\cline { 2 - 4 } & Surface hardness in HV1 & $\mathrm{CHD}_{550 \mathrm{HV} 1}$ in $\mathrm{mm}$ & $\begin{array}{c}\text { Grain size distribution complies } \\
\text { with ISO 6336-5 }\end{array}$ \\
\hline 46R & 733 & 1.29 & Yes \\
\hline $36 \mathrm{R}$ & 699 & 1.13 & Yes \\
\hline
\end{tabular}

For comparison, the $\mathrm{CHD}_{550 \mathrm{HV} 1}$ of the test series should either be equal to, higher than, or a maximum of $5 \%$ below the reference $\mathrm{CH}$ $\mathrm{D}_{550 \mathrm{HV} 1}$. $\mathrm{CHD}_{550 \mathrm{HV} 1 \text {,threshold: }}$ OW4 $=1.23 \mathrm{~mm}$ and $\mathrm{OW} 3=1.07 \mathrm{~mm}$. The value of $5 \%$ was freely selected. This serves only to distinguish between the variants and should not be considered absolute. In addition, the cumulative grain area fraction must not intersect the area that is not allowed pursuant to ISO 6336, Part 5 [12].

For all variants of the heating rate variation, the surface hardness is within the specifications (see Table 16). All four variants display rather similar case-hardening depths to the corresponding reference variant. The grain size of variant $43 \mathrm{R}$ is slightly worse than for reference variant 46R, but still acceptable. However, a slower heating rate leads to a much coarser grain with variant $33 \mathrm{R}$ than with the reference variant 36R. However, for variants $41 R$ and $31 R$, the cumulative grain area fraction intersects with the non-allowed area pursuant to ISO 6336, Part 5 [12]. Here, variant 41R has a much poorer grain size than variant $31 \mathrm{R}$.

The duration in the furnace was 360 minutes for all four variants (see Table 6). As a result, all variants display a virtually equal case-hardening depth, and the CHD is not affected by variation of durchweg innerhalb der Spezifikationen (660 bis $800 \mathrm{HV}$ ) der ISO 6336, Teil 5 [12].

Zum Vergleich sollte der $\mathrm{CHD}_{550 \mathrm{HV} 1}$ der Varianten entweder gleich, höher oder maximal $5 \%$ niedriger als der Referenzwert $\mathrm{CHD}_{550 \mathrm{HV} 1}$ sein. $\mathrm{CHD}_{550 \mathrm{HV} 1, \text { Schwellenwert }}: \mathrm{OW} 4=1,23 \mathrm{~mm}$ und OW3 = 1,07 mm. Der Wert von $5 \%$ wurde frei gewählt. Er dient lediglich der Unterscheidung zwischen den Varianten und ist nicht als absolut zu betrachten. Außerdem darf der kumulative Kornflächenanteil den nach ISO 6336, Teil 5 [12] nicht zulässigen Bereich nicht durchschneiden.

Bei allen Varianten der Heizratenvariation liegt die Oberflächenhärte innerhalb der Spezifikationen (siehe Tabelle 16). Alle vier Varianten zeigen recht ähnliche Einsatzhärtungstiefen wie die entsprechende Referenzvariante. Die Korngröße der Variante 43R ist etwas schlechter als bei der Referenzvariante 46R, aber immer noch akzeptabel. Eine langsamere Aufheizrate führt jedoch bei der Variante 33R zu einem wesentlich gröberen Korn als bei der Referenzvariante 36R. Bei den Varianten 41R und 31R schneidet der kumulative Kornflächenanteil jedoch den nicht zulässigen Bereich nach ISO 6336, Teil 5 [12]. Dabei weist die Variante 41R eine wesentlich schlechtere Korngröße auf als die Variante 31R.

Die Ofenverweildauer betrug für alle vier Varianten 360 Minuten (siehe Tabelle 6). Infolgedessen weisen alle Varianten eine nahezu gleiche Einsatzhärtungstiefe auf und die CHD wird durch die

Table 16. 'Heating rate' variation

- comparison of results

Tabelle 16. Variation der „Aufheizrate”-Vergleich der Ergebnisse

\begin{tabular}{|c|c|c|}
\hline Variant & $\begin{array}{c}\mathrm{CHD}_{550 \mathrm{HV} 1} \\
\text { in } \mathrm{mm}\end{array}$ & $\begin{array}{c}\text { Grain size distribution complies with ISO 6336-5 (information in brackets states } \\
\text { whether grain size is better or worse than reference variant 46R or 36R respectively) }\end{array}$ \\
\hline $43 \mathrm{R}$ & 1.33 & Yes (slightly coarser than reference variant) \\
\hline $41 \mathrm{R}$ & 1.28 & No \\
\hline $33 \mathrm{R}$ & 1.17 & Yes (worse than reference variant) \\
\hline $31 \mathrm{R}$ & 1.16 & No \\
\hline
\end{tabular}


the heating rate. The faster heating rate of the reference variants $46 \mathrm{R}$ and $36 \mathrm{R}$ of $6 \mathrm{~K} / \mathrm{min}$ seems more beneficial in terms of grain size. The slower heating rate of $1 \mathrm{~K} / \mathrm{min}$ leads to a coarser grain with both steel batches. The heating rate of $3 \mathrm{~K} / \mathrm{min}$ leads to a much lower grain quality for steel batch OW3 (18CrNiMo7-6), whereas for steel batch OW4 $(20 \mathrm{MnCr} 5)$ the heating rate of $3 \mathrm{~K} / \mathrm{min}$ has virtually no visible effect on the grain size. Steel batch OW4 appears not so responsive to the heating rate of $3 \mathrm{~K} / \mathrm{min}$, but is more sensitive than steel batch OW3 to the lower heating rate of $1 \mathrm{~K} / \mathrm{min}$.

The aluminum to nitrogen ratio of steel batch OW4 is $2.58: 1$, while that of batch OW3 is 1.92:1 (compare Table 3). A ratio of aluminum to nitrogen of approx. $3: 1$ should be aimed for to enable the formation of a sufficient number and size of aluminum nitrides $[28,29]$. The higher ratio of steel batch OW4 could explain why variants $46 \mathrm{R}$ and $43 \mathrm{R}$ display an almost equal grain size distribution, whereas differences are already visible between the variants 36R and 33R. However, the higher ratio does not explain why the difference between variants $43 \mathrm{R}$ and variant $41 \mathrm{R}$ is much bigger than the difference between variants $33 \mathrm{R}$ and $31 \mathrm{R}$ nor why variant $41 \mathrm{R}$ shows considerably coarser grain than variant $31 \mathrm{R}$.

The case-hardening depth of all four variants of the equal furnace duration time variation are below specifications; see Table 17. This is because the shorter time at carburizing temperature means that there is a shorter time available for carbon to diffuse into the material. The lower time at carburizing temperature also leads to a lower CHD value than in the reference variants. All variants display a coarser grain than the reference variant. Although variant $33 \mathrm{~K}$ does not intersect the non-allowed area pursuant to ISO 6336, Part 5 [12], it has a much coarser grain size than reference variant 36R. The cumulative grain area fraction of the other three variants do intersect the non-allowed area.

Variants $43 \mathrm{R}$ and $43 \mathrm{~K}$ on the one hand and variants $33 \mathrm{R}$ and $33 \mathrm{~K}$ on the other each show similar grain sizes. The shorter time at carburizing temperature for the $3 \mathrm{~K}$ variations does not appear to have a great influence on grain size. However, the case-hardening depth is lower due to the shorter time at carburizing temperature and is in this case below the specified threshold. The grain size distribution of variant $41 \mathrm{~K}$ is finer than the grain size of variant 41R. In contrast, the grain size distribution of variants $31 \mathrm{~K}$ and $31 \mathrm{R}$ are almost similar. However, the $1 \mathrm{~K}$ variations show the lowest case-hardening depth values of all the variants investigated. It
Variation der Aufheizgeschwindigkeit nicht beeinflusst. Die schnellere Aufheizrate der Referenzvarianten $46 \mathrm{R}$ und $36 \mathrm{R}$ von $6 \mathrm{~K} / \mathrm{min}$ scheint im Hinblick auf die Korngröße vorteilhafter zu sein. Die langsamere Aufheizrate von $1 \mathrm{~K} / \mathrm{min}$ führt bei beiden Stahlchargen zu einem gröberen Korn. Die Aufheizrate von $3 \mathrm{~K} / \mathrm{min}$ führt bei der Stahlcharge OW3 (18CrNiMo7 6) zu einer deutlich geringeren Kornqualität, während bei der Stahlcharge OW4 (20MnCr5) die Aufheizrate von $3 \mathrm{~K} / \mathrm{min}$ praktisch keinen sichtbaren Einfluss auf die Korngröße hat. Die Stahlcharge OW4 scheint nicht so empfindlich auf die Aufheizrate von $3 \mathrm{~K} / \mathrm{min}$ zu reagieren, reagiert aber empfindlicher als die Stahlcharge OW3 auf die niedrigere Aufheizrate von $1 \mathrm{~K} / \mathrm{min}$.

Das Verhältnis von Aluminium zu Stickstoff beträgt bei der Stahlcharge OW4 2,58: 1, während es bei der Charge OW3 1,92:1 beträgt (vgl. Tabelle 3). Ein Verhältnis von Aluminium zu Stickstoff von ca. 3:1 sollte angestrebt werden, um die Bildung einer ausreichenden Anzahl und Größe von Aluminiumnitriden zu ermöglichen $[28,29]$. Das höhere Verhältnis der Stahlcharge OW4 könnte erklären, warum die Varianten 46R und 43R eine nahezu gleiche Korngrößenverteilung aufweisen, während zwischen den Varianten 36R und 33R bereits Unterschiede erkennbar sind. Das höhere Verhältnis erklärt jedoch nicht, warum der Unterschied zwischen den Varianten 43R und 41R viel größer ist als der Unterschied zwischen den Varianten 33R und 31R und warum die Variante 41R ein wesentlich gröberes Korn aufweist als die Variante 31R.

Die Einsatzhärtungstiefe liegt bei allen vier Varianten der gleichen Ofenverweildauer unter den Vorgaben; siehe Tabelle 17. Dies ist darauf zurückzuführen, dass die kürzere Zeit bei Aufkohlungstemperatur bedeutet, dass weniger Zeit für die Diffusion von Kohlenstoff in den Werkstoff zur Verfügung steht. Die geringere Zeit bei der Aufkohlungstemperatur führt auch zu einem niedrigeren CHDWert als bei den Referenzvarianten. Alle Varianten weisen ein gröberes Korn auf als die Referenzvariante. Obwohl die Variante 33K den nicht zulässigen Bereich nach ISO 6336, Teil 5 [12] nicht durchschneidet, weist sie eine deutlich gröbere Korngröße als die Referenzvariante 36R auf. Der kumulative Kornflächenanteil der anderen drei Varianten durchschneidet den nicht zulässigen Bereich.

Die Varianten 43R und 43K auf der einen Seite und die Varianten 33R und 33K auf der anderen Seite weisen jeweils ähnliche Korngrößen auf. Die kürzere Zeit bei der Aufkohlungstemperatur bei den 3K-Varianten scheint keinen großen Einfluss auf die Korngröße zu haben. Allerdings ist die Einsatzhärtungstiefe aufgrund der kürzeren Aufkohlungszeit geringer und liegt in diesem Fall unter dem vorgegebenen Grenzwert. Die Korngrößenverteilung der Variante $41 \mathrm{~K}$ ist feiner als die Korngröße der Variante 41R. Im Gegensatz dazu sind die Korngrößenverteilungen der Varianten $31 \mathrm{~K}$ und $31 \mathrm{R}$ fast gleich. Allerdings weisen die $1 \mathrm{~K}$-Varianten die

\begin{tabular}{|c|c|c|}
\hline Variant & $\begin{array}{c}\mathrm{CHD}_{550 \mathrm{HV} 1} \\
\text { in } \mathrm{mm}\end{array}$ & $\begin{array}{c}\text { Grain size distribution complies with ISO 6336-5 (information in brackets states } \\
\text { whether grain size is better or worse than reference variant 46R or 36R respectively) }\end{array}$ \\
\hline $43 \mathrm{~K}$ & 1.11 & No \\
\hline $41 \mathrm{~K}$ & 0.52 & No \\
\hline $33 \mathrm{~K}$ & 0.99 & Yes (worse than reference variant) \\
\hline $31 \mathrm{~K}$ & 0.38 & No \\
\hline
\end{tabular}

Table 17. 'Equal furnace duration time' variation - comparison of results

Tabelle 17. Variation der „Gleichen Ofenverweildauer”Vergleich der Ergebnisse 
seems that the time spent at carburizing temperature has an effect on the grain size of steel batch OW4, whereas for steel batch OW3 there is virtually no visible effect. All in all, the $3 \mathrm{~K}$ and $1 \mathrm{~K}$ variations basically show that it is primarily the slower heating rate that has a negative effect on grain size and not the longer furnace duration time caused by a slower heating rate.

Four of the six variants in Table 18 show a case-hardening depth below the threshold. Only two variants are still in the acceptable range but are below the reference variant. Variant 361 only just does avoids intersecting the non-allowed area acc. to ISO 6336, Part 5 [12] and shows a much coarser grain than the reference variant. All of the other five variants intersect the non-allowed area.

The heat treatment parameters for the holding level variation were already known and it was expected that they would result in coarse grain and a lower case-hardening depth. However, the extent of the effects was not yet known for these ultra-clean gear steels. When a specimen was held at a level close to or at the transformation temperature during case-hardening, the grains generally became coarser. The kink in the temperature-time sequence of steel batch OW4 due to allotropic transformation is around $780^{\circ} \mathrm{C}$ and can be clearly seen in Figure 3. Both steel batches show the worst grain size at the holding level at a temperature of $780 \mathrm{C}$.

As steel batch OW4 $(20 \mathrm{MnCr} 5)$ has a transition temperature close to $780^{\circ} \mathrm{C}$ (mean value acc. to [30]), holding at $780^{\circ} \mathrm{C}$ is the most detrimental with respect to grain growth (see Table 14). The 18CrNiMo7-6 material (OW3) has a slightly lower transformation temperature of around $775{ }^{\circ} \mathrm{C}$ (mean value acc. to [31]). Consequently, for a soaking temperature of $750{ }^{\circ} \mathrm{C}$, test series 365 (OW3) shows significantly stronger grain coarsening than test series 465 (OW4). On the other hand, a holding step at a temperature level of $810^{\circ} \mathrm{C}$ produces a very mixed grain microstructure, especially for steel batch OW4. The temperature of $780^{\circ} \mathrm{C}$ has a particularly negative effect on the grain size of steel batch OW3 (specimen 368). In a direct comparison, specimen 361 , held at $810^{\circ} \mathrm{C}$, has the finest grain size. At $810^{\circ} \mathrm{C}$, the transformation is already largely complete in material $18 \mathrm{CrNiMo} 7-6$, and the microstructure is already in the austenite region during holding, although the soaking temperature of $750{ }^{\circ} \mathrm{C}$ (specimen 365) is still very slightly below trans- geringsten Einsatzhärtetiefenwerte aller untersuchten Varianten auf. Es scheint, dass die Dauer der Aufkohlungstemperatur einen Einfluss auf die Korngröße der Stahlcharge OW4 hat, während bei der Stahlcharge OW3 praktisch kein Einfluss erkennbar ist. Insgesamt zeigen die $3 \mathrm{~K}$ - und $1 \mathrm{~K}$-Varianten im Wesentlichen, dass sich vor allem die langsamere Aufheizrate negativ auf die Korngröße auswirkt und nicht die längere Ofenverweildauer, die durch eine langsamere Aufheizrate verursacht wird.

Vier der sechs Varianten in Tabelle 18 weisen eine Einsatzhärtungstiefe unterhalb des Grenzwertes auf. Nur zwei Varianten liegen noch im akzeptablen Bereich, aber unterhalb der Referenzvariante. Die Variante 361 schneidet nur knapp den nicht zulässigen Bereichs nach ISO 6336, Teil 5 [12] nicht und zeigt ein deutlich gröberes Korn als die Referenzvariante. Alle anderen fünf Varianten durchschneiden den nicht zulässigen Bereich.

Die Wärmebehandlungsparameter für die Haltestufenvariation waren bereits bekannt und es wurde erwartet, dass sie zu einer groben Korngröße und einer geringeren Einsatzhärtungstiefe führen würden. Das Ausmaß der Auswirkungen war jedoch für diese hochreinen Zahnradstähle noch nicht bekannt. Wenn eine Probe während der Einsatzhärtung auf einem Niveau nahe oder bei der Umwandlungstemperatur gehalten wurde, wurden die Körner im Allgemeinen gröber. Der Knick im Temperatur-Zeit-Verlauf der Stahlcharge OW4 aufgrund der allotropen Umwandlung liegt bei etwa $780^{\circ} \mathrm{C}$ und ist in Bild 3 deutlich zu erkennen. Beide Stahlchargen zeigen die schlechteste Korngröße auf dem Halteniveau bei einer Temperatur von $780^{\circ} \mathrm{C}$.

Da die Stahlcharge OW4 (20MnCr5) eine Umwandlungstemperatur in der Nähe von $780^{\circ} \mathrm{C}$ hat (Mittelwert nach [30]), ist das Halten bei $780^{\circ} \mathrm{C}$ im Hinblick auf das Kornwachstum am ungünstigsten (siehe Tabelle 14). Der Werkstoff 18CrNiMo7-6 (OW3) hat eine etwas niedrigere Umwandlungstemperatur von etwa $775^{\circ} \mathrm{C}$ (Mittelwert nach [31]). Folglich zeigt die Versuchsreihe 365 (OW3) bei einer Haltetemperatur von $750^{\circ} \mathrm{C}$ eine deutlich stärkere Kornvergröberung als die Versuchsreihe 465 (OW4). Ein Halteschritt bei einem Temperaturniveau von $810^{\circ} \mathrm{C}$ führt dagegen zu einem sehr gemischtkörnigen Gefüge, insbesondere bei der Stahlcharge OW4. Die Temperatur von $780^{\circ} \mathrm{C}$ wirkt sich besonders negativ auf die Korngröße der Stahlcharge OW3 (Probe 368) aus. Im direkten Vergleich weist die Probe 361 , die bei $810^{\circ} \mathrm{C}$ gehalten wurde, die feinste Korngröße auf. Bei $810^{\circ} \mathrm{C}$ ist die Umwandlung im Werkstoff 18CrNiMo7-6 bereits weitgehend abgeschlossen und das Gefüge befindet sich bereits während des Haltens im Austenitbereich, ob-
Table 18. 'Soaking temperature' variation - comparison of the results

Tabelle 18. Variation „Haltetemperatur" -Vergleich der Ergebnisse

\begin{tabular}{|c|c|c|}
\hline Variant & $\begin{array}{c}\mathrm{CHD}_{550 \mathrm{HV} 1} \\
\text { in } \mathrm{mm}\end{array}$ & $\begin{array}{c}\text { Grain size distribution complies with ISO 6336-5 (information in brackets states } \\
\text { whether grain size is better or worse than reference variant 46R or 36R respectively) }\end{array}$ \\
\hline 465 & 1.26 & No \\
\hline 468 & 1.20 & No \\
\hline 461 & 1.20 & No \\
\hline 365 & 0.97 & No \\
\hline 368 & 0.99 & No \\
\hline 361 & 1.08 & Yes (much worse than reference variant) \\
\hline
\end{tabular}


formation. This has a stronger effect on grain growth than holding at $810^{\circ} \mathrm{C}$ in the austenite region.

It can be concluded that an additional holding level in the transformation zone during heating has a negative effect on case-hardening depth and the grain size of ultra-clean gear steels. The transformation zone must be passed through as fast as possible to avoid coarse grain.

It can be seen that with the exception of one variant, all the variants investigated here produced worse results than the respective reference variant, whether surface hardness, CHD, or grain size. The first conclusion is that ultra-clean gear steels labelled as fine-grained are actually not necessarily fine-grained after inappropriate heat treatment. A low heating rate, perhaps due to dense charging or insufficient furnace power, usually results in unacceptable grain growth. It is important to bear this in mind for larger gear sizes, as very often high heating rates cannot be attained with these. The heating rate also tends to impact more greatly on grain growth than holding for an extended period at carburization temperature.

In general, maintaining a constant temperature close to the transformation temperature for a certain time induces significant grain growth. This is also confirmed here for ultra-clean gear steels. If the temperature is held significantly below or further into the austenite region, it has a considerably smaller effect.

Recommendations for the heat treatment of (ultra-clean) carburizing steels:

- Slow heating rates during case-hardening have a large impact on grain size. A furnace should therefore not be loaded too densely, as areas towards the center of load may experience a slower heating rate. As stated above, this problem can arise with large gear sizes as well as with furnaces with insufficient power.

- If a holding level is needed for heating in a case carburizing process, for instance, to minimize distortion by equalizing the temperature in the component, a temperature should be chosen that is well below (or above) the transformation temperature.

\section{Summary and subsequent steps}

In high-strength gears, tooth root breakage can occur due to a crack initiation below the material surface at a non-metallic inclusion. The aim of FVA research project 293 IV [15] was to derive a correlation between the degree of cleanliness and the tooth root bending strength. The state of scientific knowledge shows that the case-hardening depth and the grain size can also have a great influence on the load carrying capacity of gears. For this reason, any cross-influences should be excluded or minimized, or at least be known, to ensure that only the influence of non-metallic inclusions is investigated. For example, even gear steels with high fine- wohl die Haltetemperatur von $750{ }^{\circ} \mathrm{C}$ (Probe 365) noch sehr knapp unter der Umwandlung liegt. Dies hat einen stärkeren Einfluss auf das Kornwachstum als das Halten bei $810^{\circ} \mathrm{C}$ im Austenitbereich.

Daraus kann gefolgert werden, dass ein zusätzliches Halten in der Umwandlungszone während der Erwärmung einen negativen Einfluss auf die Einsatzhärtetiefe und die Korngröße von hochreinen Zahnradstählen hat. Die Umwandlungszone muss so schnell wie möglich durchlaufen werden, um Grobkorn zu vermeiden.

Es zeigt sich, dass mit Ausnahme einer Variante alle hier untersuchten Varianten schlechtere Ergebnisse als die jeweilige Referenzvariante lieferten, sei es bei der Oberflächenhärte, der CHD oder der Korngröße. Die erste Schlussfolgerung ist, dass hochreine Zahnradstähle, die als feinkörnig bezeichnet werden, nach einer unangemessenen Wärmebehandlung nicht unbedingt feinkörnig sind. Eine niedrige Aufheizrate, vielleicht aufgrund einer dichten Beladung oder unzureichender Ofenleistung, führt in der Regel zu einem inakzeptablen Kornwachstum. Dies ist bei größeren Zahnradgrößen zu beachten, da hier oft keine hohen Aufheizraten erreicht werden können. Die Aufheizgeschwindigkeit wirkt sich in der Regel auch stärker auf das Kornwachstum aus als ein längeres Halten auf Aufkohlungstemperatur.

Im Allgemeinen führt das Halten einer konstanten Temperatur in der Nähe der Umwandlungstemperatur über einen bestimmten Zeitraum zu einem erheblichen Kornwachstum. Dies wird auch hier für die hochreinen Zahnradstähle bestätigt. Wird die Temperatur deutlich unterhalb oder weiter im Austenitbereich gehalten, ist die Wirkung deutlich geringer.

Empfehlungen für die Wärmebehandlung von (hochreinen) Einsatzstählen:

- Langsame Aufheizraten während des Einsatzhärtens haben einen großen Einfluss auf die Korngröße. Ein Ofen sollte daher nicht zu dicht beladen werden, da die Bereiche zur Mitte der Beladung hin eine langsamere Aufheizgeschwindigkeit erfahren können. Wie bereits erwähnt, kann dieses Problem bei großen Zahnradgrößen sowie bei Öfen mit unzureichender Leistung auftreten.

- Ist ein Halteniveau für die Erwärmung z. B. bei einer Einsatzaufkohlung erforderlich, um den Verzug durch Temperaturausgleich im Bauteil zu minimieren, sollte eine Temperatur gewählt werden, die deutlich unter (oder über) der Umwandlungstemperatur liegt.

\section{Zusammenfassung und weitere Schritte}

Bei hochtragfähigen Zahnrädern kann ein Zahnfußbruch durch eine Rissbildung unterhalb der Werkstoffoberfläche an einem nichtmetallischen Einschluss auftreten. Ziel des FVA Forschungsvorhabens 293 IV [15] war es, einen Zusammenhang zwischen dem Reinheitsgrad und der Zahnfußtragfähigkeit abzuleiten. Der Stand des Wissens zeigt, dass auch die Einsatzhärtetiefe und die Korngröße einen großen Einfluss auf die Tragfähigkeit von Zahnrädern haben können. Aus diesem Grund sollten eventuelle Quereinflüsse ausgeschlossen oder minimiert werden oder zumindest bekannt sein, damit nur der Einfluss nichtmetallischer Einschlüsse 
grain stability may contain coarser grains after inappropriate heat treatment. However, no recommendations or investigations regarding the influence of the case-hardening process on material properties were available for such ultra-clean gear steels.

In the framework of this paper, extended investigations into the influence of different process steps during case-hardening were performed on the resulting material properties of two batches of ultra-clean gear steels. The fine-grain stability of the ultra-clean gear steels was also investigated. Some of the chosen heat treatment parameters are already known to lead to coarse grain and worse hardenability. However, the extent of the effects is not yet known for these ultra-clean gear steels.

The main findings of this paper are:

- Ultra-clean gear steels labelled as fine-grained are not necessarily fine-grained after unsuitable heat treatment, especially when held at a temperature near the allotropic transformation zone.

- A low heating rate, due to dense charging or insufficient furnace power, usually results in unacceptable grain growth. This should be kept in mind for larger gear sizes, as very often, high heating rates cannot be attained with these. The heating rate also tends to impact more greatly on grain growth than holding at carbonization temperature for an extended period.

Gear steels often undergo either ferritic-pearlitic annealing to improve their machinability or quenching and tempering for better carbon distribution in the microstructure or they are forged into a blank. Currently, there are no investigations or recommendations regarding the influence of a preheat treatment on the material properties of ultra-clean gear steels. The next step will therefore be to investigate the influence of a preheat treatment in conjunction with case-hardening on the material properties of ultra-clean gear steels. These findings will be published in a subsequent article.

\section{Acknowledgments}

The underlying research work [15] was funded in equal proportions by the "Forschungsvereinigung der Arbeitsgemeinschaft der Eisen und Metall verarbeitenden Industrie e.V. (AVIF)" (A 305/S 0024/10235/16) and the "Forschungsvereinigung Antriebstechnik e.V. (FVA)" The results presented in this paper were taken from the FVA research project 293 IV "Späte Zahnfußbrüche/ Reinheitsgrad II" [15]. More detailed information on the influence of non-metallic inclusions, especially in the very high cycle range, is given in the final report. untersucht wird. So können z. B. auch Zahnradstähle mit hoher Feinkornstabilität nach unsachgemäßer Wärmebehandlung gröbere Körner enthalten. Für solche hochreinen Zahnradstähle lagen jedoch keine Empfehlungen oder Untersuchungen zum Einfluss des Einsatzhärtungsprozesses auf die Werkstoffeigenschaften vor.

Im Rahmen dieser Veröffentlichung wurden erweiterte Untersuchungen zum Einfluss verschiedener Prozessschritte beim Einsatzhärten auf die resultierenden Werkstoffeigenschaften von zwei Chargen hochreiner Zahnradstähle durchgeführt. Auch die Feinkornstabilität der hochreinen Zahnradstähle wurde untersucht. Von einigen der gewählten Wärmebehandlungsparameter ist bereits bekannt, dass sie zu grobem Korn und schlechterer Härtbarkeit führen. Das Ausmaß der Auswirkungen ist jedoch für diese hochreinen Zahnradstähle noch nicht bekannt.

Die wichtigsten Ergebnisse dieser Arbeit sind:

- Hochreine Zahnradstähle, die als feinkörnig bezeichnet werden, sind nach einer ungeeigneten Wärmebehandlung nicht unbedingt feinkörnig, insbesondere wenn sie bei einer Temperatur nahe der allotropen Umwandlungszone gehalten werden.

- Eine niedrige Aufheizrate aufgrund einer dichten Beladung oder unzureichender Ofenleistung führt in der Regel zu einem inakzeptablen Kornwachstum. Dies sollte bei größeren Zahnrädern beachtet werden, da bei diesen häufig keine hohen Aufheizraten erreicht werden können. Die Aufheizrate wirkt sich in der Regel auch stärker auf das Kornwachstum aus als das Halten auf Aufkohlungstemperatur über einen längeren Zeitraum.

Zahnradstähle werden häufig entweder ferritisch-perlitisch geglüht, um ihre Bearbeitbarkeit zu verbessern, oder vergütet, um eine bessere Kohlenstoffverteilung im Gefüge zu erreichen, oder sie werden zu einem Rohling geschmiedet. Derzeit gibt es keine Untersuchungen oder Empfehlungen zum Einfluss einer Vorwärmebehandlung auf die Werkstoffeigenschaften von hochreinen Zahnradstählen. In einem nächsten Schritt soll daher der Einfluss einer Vorwärmebehandlung in Verbindung mit dem Einsatzhärten auf die Werkstoffeigenschaften von hochreinen Zahnradstählen untersucht werden. Diese Ergebnisse werden in einem späteren Artikel veröffentlicht.

\section{Danksagung}

Die zugrunde liegenden Forschungsarbeiten [15] wurden zu gleichen Teilen von der Forschungsvereinigung der Arbeitsgemeinschaft der Eisen und Metall verarbeitenden Industrie e.V. (AVIF) (A 305/S 0024/10235/16) und der Forschungsvereinigung Antriebstechnik e.V. (FVA) gefördert. Die in dieser Veröffentlichung vorgestellten Ergebnisse stammen aus dem FVA-Forschungsvorhaben 293 IV "Späte Zahnfußbrüche/ Reinheitsgrad II" [15]. Ausführlichere Informationen über den Einfluss nichtmetallischer Einschlüsse, insbesondere im Bereich hoher Lastspielzahlen, sind im Abschlussbericht enthalten.

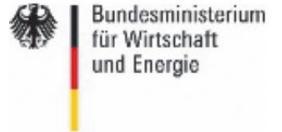
Bundesministerium
tür Wirtschaft
und Energie

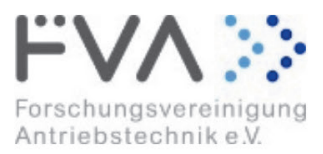

Antriebstechnik e.V.

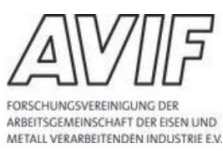




\section{References}

1. Niemann, G.; Winter, H.: Maschinenelemente: Band 2: Getriebe allgemein, Zahnradgetriebe - Grundlagen, Stirnradgetriebe, 2. Aufl., Springer Vieweg, Berlin, Heidelberg, 2003. - ISBN: 9783662118740

2. Brugger, H.: Einsatzhärten von Zahnrädern. Voraussetzung zur Erzielung reproduzierbarer hoher Zahnfußtragfähigkeit. Antriebstechnik 18 (1979) 9, pp. 431-437

3. Funatani, K.: Einfluß von Einsatzhärtungstiefe und Kernhärte auf die Biegedauerfestigkeit von aufgekohlten Zahnrädern. HTM Härterei-Technische Mitteilungen 25 (1970) 2, pp. 92-98

4. Börnecke, K.: Grundlagenversuche zur Ermittlung der richtigen Härtetiefe bei Wälz- und Biegebeanspruchungen. FVA, Forschungsheft 8, Frankfurt a. M., 1976

5. Güntner, C.: Härtbarkeit Großzahnräder: Einflüsse aus Baugröße, Härtbarkeit und Einsatzhärtungstiefe und deren Gesamtwirkung auf die Zahnfußtragfähigkeit einsatzgehärteter Stirnräder größerer Baugröße. FVA, Forschungsvorhaben 740 I, Frankfurt a. M., 2018

6. Tobie, T.: Härtetiefe-Großzahnräder: Einfluss der Einsatzhärtetiefe auf die Grübchen und Zahnfußtragfähigkeit großer Zahnräder. FVA, Forschungsvorhaben 271, Frankfurt a. M., 2001

7. Mallener, H.; Schulz, M.: Wärmebehandlung von Zahnrädern. Proc. AWT Tagung Randschichtermüdung im Wälzkontakt, 06.-07.05.1992, Suhl, AWT, Bremen, 1992, pp. 93-110

8. Flesch, R.; Spitzer, H.; Bleck, W.: Korngrößeneinfluss auf die Eigenschaften von Einsatzstählen - Feinkornstabilität bei erhöhten Aufkohlungstemperaturen: Feinkornsthl - Literaturrecherche. FVA, Frankfurt a. M., 1998

9. Sauter, J.; Schmidt, I.; Schulz, M.: Einflußgrößen auf die Leistungsfähigkeit einsatzgehärteter Zahnräder. HTM Härterei-Techn. Mitt. 45 (1990) 2, pp. 98-104, DOI:10.1515/htm-1990-450210

10. Hippenstiel, F.: Mikrolegierte Einsatzstähle als massgeschneiderte Werkstofflösung zur Hochtemperaturaufkohlung von Getriebekomponenten. Dissertation, RWTH Aachen, 2001

11. Kleemaier, R.; Michelitsch, M.; Kneissl, A.; Jeglitsch, F.: Auflösung von Ausscheidungen und Austenitkornwachstum beim Austenitisieren mikrolegierter Baustähle. Practical Metallography 26 (1989) 5, pp. 248-260, DOI:10.1515/ pm-1989-260505

12. ISO 6335-5 : 2016-08: Tragfähigkeitsberechnung von gerad- und schrägverzahnten Stirnrädern - Teil 5: Festigkeit und Werkstoffqualitäten. Beuth Verlag, Berlin, 2016

13. DIN EN ISO 643:2020-06: Stahl - Mikrophotographische Bestimmung der erkennbaren Korngröße. Beuth Verlag, Berlin, 2020

14. ISO 10474: 2013-07: Stahl und Stahlerzeugnisse - Prüfbescheinigungen. Beuth Verlag, Berlin, 2013

15. Fuchs, D.; Tobie, T.; Stahl, K.: Untersuchungen zum Fehlstellenversagen an Zahnrädern und deren Einfluss auf die Zahnradtragfähigkeit. FVA, Forschungsvorhaben 293 IV, Frankfurt a. M., 2021

16. Schurer, S.: Einfluss nichtmetallischer Einschlüsse in hochreinen Werkstoffen auf die Zahnfußtragfähigkeit. Dissertation, TU München, 2016

17. Bretl, N. T.: Einflüsse auf die Zahnfußtragfähigkeit einsatzgehärteter Zahnräder im Bereich hoher Lastspielzahlen. Dissertation, TU München, 2010

18. Stenico, A.: Werkstoffmechanische Untersuchungen zur Zahnfußtragfähigkeit einsatzgehärteter Zahnräder. Dissertation, TU München, 2007
19. Fuchs, D.; Schurer, S.; Tobie, T.; Stahl, K.: Investigations into non-metallic inclusion crack area characteristics relevant for tooth root fracture damages of case carburised and shot-peened high strength gears of different sizes made of high-quality steels. Forschung im Ingenieurwesen 83 (2019), DOI:10.1007/ s10010-019-00324-X

20. Bretl, N. T.; Schurer, S.; Tobie, T.; Höhn, B.: Investigations on Tooth Root Bending Strength of Case Hardened Gears in the Range of High Cycle Fatigue. Technical Paper 13FTM09, AGMA, Alexandria, VA, USA, 2013

21. Winkler, K. J.; Schurer, S.; Tobie, T.; Stahl, K.: Investigations on the tooth root bending strength and the fatigue fracture characteristics of case-carburized and shotpeened gears of different sizes. Proceedings of the Institution of Mechanical Engineers, Part C: Journal of Mechanical Engineering Science 233 (2019) 21-22, pp. 7338-7349, DOI:10.1177/0954406219841650

22. Fuchs, D.; Schurer, S.; Tobie, T.; Stahl, K.: On the determination of the bending fatigue strength in and above the very high cycle fatigue regime of shot-peened gears. Forschung im Ingenieurwesen (2021), DOI:10.1007/s10010-021-00499-2, open access

23. Schurer, S.; Tobie, T.; Stahl, K.: Tragfähigkeitsgewinn im Zahnfuß durch hochreine Stähle. FVA, Forschungsvorhaben 293 III, Frankfurt a. M., 2015

24. DIN EN ISO 683-3:2019-04: Heat-treatable steels, alloy steels and free-cutting steels - Part 3: Case-hardening steels. Beuth Verlag, Berlin, 2019

25. ISO 4967: 2013-07: Steel - Determination of content of non-metallic inclusions - Micrographic method using standard diagrams. Beuth Verlag, Berlin, 2013

26. DIN EN ISO 18265: 2014: Metallic materials - Conversion of hardness values. Beuth Verlag, Berlin, 2014

27. Thieme, L.: PixelFerber - imaging software. https://www.pixelferber.de/, 2021

28. Klenke, K.; Kohlmann, R.: Einsatzstähle in ihrer Feinkornbeständigkeit, heute und morgen.HTMJ.Heat Treatm.Mat.60(2005)5,pp. 260-270,DOI:10.3139/105.100348

29. Klenke, K.; Kohlmann, R.; Reinhold, P.; Schweinebraten, W.: Kornwachstumsverhalten des Einsatzstahles 20NiMoCr6-5 + Nb (VW $4521+\mathrm{Nb})$ für Getriebeteile beim Hochtemperaturaufkohlen. HTM J. Heat Treatm. Mat. 63 (2008) 5, pp. 265 275, DOI:10.3139/105.100468

30. Deutsche Edelstahlwerke GmbH: Cr-Mn-legierter Einsatzstahl 1.7147/1.7149: 20MnCr5/20MnCrS5. https://www.dew-stahl.com/fileadmin/files/dew-stahl.com/ documents/Publikationen/Werkstoffdatenblaetter/Baustahl/1.7147_1.7149_de. pdf, 2011 - Accessed 20 Aug 2021

31. Deutsche Edelstahlwerke GmbH: Carbodur 6587: Werkstoffdatenblatt 18CrNiMo7-6 1.6587. https://www.dew-stahl.com/fileadmin/files/dew-stahl.com/documents/ Publikationen/Werkstoffdatenblaetter/Baustahl/1.6587_de.pdf, 2016 - Accessed 20 Aug 2021

\section{Bibliography}

DOI:10.1515/htm-2021-0011

HTM J. Heat Treatm. Mat.

76 (2021) 5; page 321-339

(c) 2021 Walter de Gruyter GmbH, Berlin/Boston, Germany

ISSN 1867-2493, e-ISSN 2194-1831 